\title{
Regulation of Mesangial Cell Ion Channels by Insulin and Angiotensin II Possible Role in Diabetic Glomerular Hyperfiltration
}

Brian N. Ling, * Elisabeth E. Seal, *\$ and Douglas C. Eaton*

Departments of ${ }^{*}$ Medicine and ${ }^{\ddagger}$ Physiology, Renal Division, Emory University School of Medicine, and ${ }^{\S}$ Veterans Affairs Medical Center, Atlanta, Georgia 30322

\section{Abstract}

We used patch clamp methodology to investigate how glomerular mesangial cells (GMC) depolarize, thus stimulating voltage-dependent $\mathrm{Ca}^{2+}$ channels and GMC contraction. In rat GMC cultures grown in $100 \mathrm{mU} / \mathrm{ml}$ insulin, $12 \%$ of cell-attached patches contained a $\mathrm{Ca}^{2+}$-dependent, 4-picosiemens $\mathrm{Cl}^{-}$ channel. Basal $N P_{0}$ (number of channels times open probability) was $<0.1$ at resting membrane potential. Acute application of 1-100 $\mathrm{nM}$ angiotensin II (AII) or 0.25 $\mu \mathrm{M}$ thapsigargin (to release $\left[\mathrm{Ca}^{2+}\right]_{i}$ stores) increased $N P_{0}$. In GMC grown without insulin, $\mathrm{Cl}^{-}$channels were rare $(4 \%)$ and unresponsive to AII or thapsigargin in cell-attached patches, and less sensitive to $\left[\mathrm{Ca}^{2+}\right]_{i}$ in excised patches. GMC also contained 27-pS nonselective cation channels (NSCC) stimulated by AII, thapsigargin, or $\left[\mathrm{Ca}^{2+}\right]_{i}$, but again only when insulin was present. In GMC grown without insulin, $15 \mathrm{~min}$ of insulin exposure increased $N P_{0}$ (insulin $\geq 100 \mu \mathrm{U} / \mathrm{ml}$ ) and restored $\mathrm{AII}$ and $\left[\mathrm{Ca}^{2+}\right]_{\mathrm{i}}$ responsiveness (insulin $\geq 1 \mu \mathrm{U} / \mathrm{ml}$ ) to both $\mathrm{Cl}^{-}$and NSCC. GMC AII receptor binding studies showed a $B_{\max }$ (binding sites) of $2.44 \pm 0.58 \mathrm{fmol} / \mathrm{mg}$ protein and a $K_{d}$ (binding dissociation constant) of $3.02 \pm 2.01 \mathrm{nM}$ in the absence of insulin. $B_{\max }$ increased by $86 \%$ and $K_{d}$ was unchanged after chronic (days) insulin exposure. In contrast, neither $K_{d}$ nor $B_{\max }$ was significantly affected by acute (15-min) exposure. Therefore, we concluded that: $(a)$ rat GMC cultures contain $\mathrm{Ca}^{2+}$-dependent $\mathrm{Cl}^{-}$and NSCC, both stimulated by AII. (b) $\mathrm{Cl}^{-}$efflux and cation influx, respectively, would promote GMC depolarization, leading to voltage-dependent $\mathrm{Ca}^{2+}$ channel activation and GMC contraction. (c) Responsiveness of $\mathrm{Cl}^{-}$and NSCC to AII is dependent on insulin exposure; AII receptor density increases with chronic, but not acute insulin, and channel sensitivity to $\left[\mathrm{Ca}^{2+}\right]_{i}$ increases with both acute and chronic insulin. (d) Decreased GMC contractility may contribute to the glomerular hyperfiltration seen in insulinopenic or insulin-resistant diabetic patients. (J. Clin. Invest. 1993. 92:2141-2151.) Key words: patch clamp $\cdot \mathrm{Cl}^{-}$channel $\bullet$ nonselective cation channel • $\mathrm{Ca}^{2+}$ channel $\cdot$ diabetes mellitus

Preliminary work was presented at the American Federation for Clinical Research National Meeting, May 1992 (Clin. Res. 1992. 40:179a [Abstr.]) and the American Society of Nephrology Annual Meeting, November 1992 (J. Am. Soc. Nephrol. 1992. 3:813).

Address correspondence to Dr. Brian N. Ling, Renal Division, Emory University School of Medicine, 1364 Clifton Road, N.E., Atlanta, GA 30322. 1993.

Received for publication 21 August 1992 and in revised form 21 July

J. Clin. Invest.

(c) The American Society for Clinical Investigation, Inc.

$0021-9738 / 93 / 11 / 2141 / 11 \quad \$ 2.00$

Volume 92, November 1993, 2141-2151

\section{Introduction}

The glomerular filtration barrier consists of three layers: capillary endothelial cells, basement membrane, and Bowman's capsular epithelial cells. However, a third resident cell type found in the glomerular tuft between and within capillary loops also plays an integral role in filtration (1). These are glomerular mesangial cells (GMC), ${ }^{1}$ which phenotypically resemble smooth muscle cells and contain large numbers of myofilaments. In mesangial cells, hormonal and intracellular signaling pathways play an important role in initiating normal physiological and pathologic responses by changing both contractile and growth properties, and thereby altering glomerular filtration.

Mesangial cell contraction depends on membrane depolarization stimulating voltage-dependent $\mathrm{Ca}^{2+}$ channels (2-5). In vascular smooth muscle cells, this depolarization process involves $\mathrm{Cl}^{-}$efflux through $\mathrm{Ca}^{2+}$-dependent $\mathrm{Cl}^{-}$channels and cation influx through nonselective cation channels (6-8). Several groups have indirect evidence that mesangial cell depolarization induced by vasoactive peptides (e.g., angiotensin II [AII], vasopressin, endothelin-1, platelet activating factor) depends on activation of a $\mathrm{Ca}^{2+}$-dependent $\mathrm{Cl}^{-}$conductance (911). However, specific $\mathrm{Cl}^{-}$conductances at a single channel level have not been identified in GMC.

GMC contraction in response to vasoactive peptides has been shown to be dependent on the presence of exogenous insulin $(12,13)$. The physiologic relevance of the latter observation is that decreased GMC contractility has been proposed to contribute to the increased glomerular filtration rate ("hyperfiltration") present in insulinopenic or insulin-resistant diabetic patients (13).

In this study we used patch clamp technology to characterize ion channels capable of mediating membrane depolarization of cultured rat glomerular mesangial cells. The influence of exogenous insulin and the vasoactive peptide, AII, on the regulation of ion channels was also examined. Finally, AII receptor binding studies were performed under various conditions of exogenous insulin exposure.

\section{Methods}

Preparation of rat GMC cultures. GMC cultures were established and maintained using previously described methods $(14,15)$. Briefly, renal cortices from male Sprague-Dawley rats $(75-150 \mathrm{~g})$ were dissected. Mesangial cell-enriched glomerular cores were isolated from cortical tissue by differential sieving and incubation for 45-60 min with collagenase $(1,200 \mathrm{U} / \mathrm{ml})$ in $\mathrm{Ca}^{2+} / \mathrm{Mg}^{2+}$-free Hank's balanced salt solution (Irvine Scientific, Santa Ana, CA). The GMC suspension was washed and plated in RPMI 1640 supplemented with $17 \%$ (vol/vol) fetal bo-

1. Abbreviations used in this paper: AII, angiotensin II; GMC, glomerular mesangial cells; $\mathrm{IP}_{3}$, inositol-1,4,5-trisphosphate. 
vine serum, $2 \mathrm{mM}$ glutamine, selenium $(5 \mathrm{ng} / \mathrm{ml}$ ), antibiotics (penicillin, $100 \mathrm{U} / \mathrm{ml}$; streptomycin sulfate, $100 \mu \mathrm{g} / \mathrm{ml}$; amphotericin B, 2 $\mu \mathrm{g} / \mathrm{ml})$, and bovine insulin $(100 \mathrm{mU} / \mathrm{ml})$ at $37^{\circ} \mathrm{C}$ in $5 \% \mathrm{CO}_{2} / 95 \%$ air. The RPMI 1640 contained $11 \mathrm{mM}$ D-glucose.

Exogenous insulin exposure to mesangial cell cultures. Mesangial cell outgrowth was usually observed by day 10 , and cells reached confluency by day 21 , at which time they were trypsinized and subcultured. For chronic insulin exposure experiments, the subcultures were then grown with or without (insulin-deficient GMC cultures) bovine insulin $(100 \mathrm{mU} / \mathrm{ml})$ added to the RPMI 1640 . For acute insulin exposure experiments, insulin-deficient GMC cultures were exposed to various concentrations of bovine insulin $(1 \mu \mathrm{U} / \mathrm{ml}, 10 \mu \mathrm{U} / \mathrm{ml}, 100$ $\mu \mathrm{U} / \mathrm{ml}$, and $100 \mathrm{mU} / \mathrm{ml}$ ) in the extracellular bath for $15 \mathrm{~min}$ immediately before patching. Mesangial cell passages 5-7 were grown on glass coverslips for patch clamp experiments.

Patch clamp recording and analysis. Mesangial cells were visualized with Hoffman modulation optics mounted on a Diaphot-TMD inverted microscope (Nikon Inc., Instr. Group, Melville, NY). Patch pipettes are fabricated from Microhematocrit (blue coded tip) capillary tubes (Fisher Scientific, Pittsburgh, PA) and positioned with a motorized micromanipulator system (Newport Corp., Irvine, CA) as previously described (16). All experiments were conducted at $37^{\circ} \mathrm{C}$ using a temperature controller and open perfusion micro-incubator (TC-202 and PDMI-2; Medical Sys. Corp., Greenvale, NY). Unitary channel events were obtained using a List patch clamp (EPC-7; Medical Sys. Corp.), digitized by a pulse code modulator (DAS 601; Dagan Corp., Minneapolis, $\mathrm{MN}$ ), and recorded on a video cassette recorder (SLHF860D; Sony Corp. of America, Park Ridge, NJ). Data were acquired using a eight-pole Bessel filter (902LPF; Frequency Devices Inc., Haverhill, MA), acquisition hardware and Axotape software (TL2; Axon Instrs. Inc., Foster City, CA), and a computer (486SX; Mitsuba Southeast, Inc., Norcross, GA) (corner frequency $=1 \mathrm{KHz}$; sampled at $200 \mu$ s/point).

Patch pipettes contained a physiologic saline solution of: ( $\mathrm{mM}) 140$ $\mathrm{NaCl}$ (final $\mathrm{NaCl}$ concentration after titration to $\mathrm{pH} 7.4$ with $\mathrm{NaOH}$ ), $5 \mathrm{KCl}, 1 \mathrm{CaCl}_{2}, 1 \mathrm{MgCl}_{2}$, and 10 Hepes. The extracellular bath solution for cell-attached patches was the same as the patch pipette solution above. The "cytoplasmic" solution for most excised inside-out patches approximated intracellular composition of: (mM) $140 \mathrm{KCl}$ (final KCl concentration after titration to $\mathrm{pH} 7.4$ with $\mathrm{KOH}$ ), $5 \mathrm{NaCl}, 1 \mathrm{MgCl}_{2}$, $0.001 \mathrm{CaCl}_{2}, 2$ EGTA, and 10 Hepes (Table I, solution A). For cytoplasmic $\mathrm{Ca}^{2+}$ exchange experiments, a computer program using known stability constants calculated the amount of $\mathrm{Ca}^{2+}$ needed to vary the final free ionized $\mathrm{Ca}^{2+}$ concentration in solution $\mathrm{A}$ between $10^{-8}$ and $10^{-4} \mathrm{M}(17)$.

The convention for applied voltage to the membrane patch $\left(-V_{\text {pipet }}\right)$ represents the voltage deflection from the patch potential (i.e., the resting membrane potential for cell-attached patches; $0 \mathrm{mV}$ for inside-out patches) and is expressed as the potential of the cell interior with respect to the patch pipette interior (i.e., negative values = hyperpolarization; positive values $=$ depolarization $)$. Inward current (pipette to cell) is represented as downward transitions in single channel records. Analysis of data was performed on a computer (486SX; Mitsuba Southeast Inc., Norcross, GA) using locally and commercially developed software.

The total number of functional channels $(N)$ in the patch are estimated by observing the number of peaks detected on current amplitude histograms. As a measure of channel activity, $N P_{\mathrm{o}}$ (number of channels times the open probability) is calculated (18).

$N P_{\mathrm{o}}=\sum_{n=0}^{N} \frac{n \cdot t_{n}}{T}$

where $T$ is the total record time, $n$ is the number of channels open, and $t_{n}$ is the record time during which $n$ channels are open. Therefore, $N P_{\circ}$ can be calculated without making assumptions about the total number of channels in a patch or the open probability of a single channel. The probability that any one channel is open $\left(P_{0}\right)$ is calculated from the expression (16):
$P_{\mathrm{o}}=\left(\sum_{n=1}^{N} P_{n}\right) / N$

where $P_{n}$ is, the probability that $n$ channels are open, calculated as the amount of time in the open state divided by the total record time for each unitary current level. Summation of $P_{n}$ 's for each level are then divided by $N$. The assumptions for this calculation are that the channels function independently and identically, and that $n$ channels are open when the current is between $(n-1 / 2) i$ and $(n+1 / 2) i$, where $i$ is the unit current.

Relative ion permeability ratios for GMC channels were calculated using a modification of the Goldman-Hodgkin-Katz equation (given below).

$E_{\text {rev }}=\frac{R T}{F} \ln \frac{P_{K}[K]_{0}+P_{N a}[N a]_{0}+P_{C l}[C l]_{i}}{P_{K}[K]_{i}+P_{N a}[N a]_{i}+P_{C C}[C l]_{0}}$, where

$[\mathrm{K}]_{0},[\mathrm{Na}]_{0}$, and $[\mathrm{Cl}]_{0}$ are the concentration of these ions on the outside surface of the apical membrane (pipette solution); $[K]_{i},[N a]_{i}$, and $[\mathrm{Cl}]_{i}$ are the concentrations on the inner surface (cytoplasmic bath solution); and $P_{K}, P_{N a}$, and $P_{C l}$ are the relative ion permeabilities.

Statistics. Experiments in the cell-attached or excised inside-out patch configuration were conducted in a paired fashion; data from each patch membrane served as the control for an experimental manipulation. Data are reported as mean $N P_{\mathrm{o}}$ or $P_{\mathrm{o}}$ values $\pm 1 \mathrm{SD}$.

The average change in $N P_{\mathrm{o}}$ or $P_{\mathrm{o}}$ for a group of patches, compared before and after an experimental manipulation, was also analyzed using the paired $t$ test (19):

$t=\frac{\bar{x}-\mu}{s / \sqrt{n}}$

where $\bar{x}$ is the average change in $N P_{\mathrm{o}}$ or $P_{\mathrm{o}}, \mu$ (hypothesis that $\bar{x}$ will be different from zero) $=0, s$ is the SD for $\bar{x}$, and $n$ is the number of patches. Significance was $P<0.05$. This approach reduces the variability in the observations due to differences in ion channel activity between individual patches and yields a more sensitive test than comparing the mean $N P_{\mathrm{o}}$ or $P_{\mathrm{o}}$ responses (19).

AII receptor binding assay. AII receptor binding assays were performed as previously described (20-23). Rat GMC were grown to $\sim 80-90 \%$ confluency in 24-well plates (Falcon 3047; Fisher Scientific) under the same exogenous insulin exposure conditions described above. GMC were washed twice with $0.4 \mathrm{ml}$ of ice-cold binding buffer containing $50 \mathrm{mM}$ Tris- $\mathrm{HCl}, 100 \mathrm{mM} \mathrm{NaCl}, 5 \mathrm{mM} \mathrm{MgCl}$, and $0.2 \%$ $\mathrm{BSA}, \mathrm{pH}$ 7.4. The cells were then incubated in the above buffer with ${ }^{125} \mathrm{I}$-AII at varying concentrations for $90 \mathrm{~min}$ at $4^{\circ} \mathrm{C}$ to prevent receptor internalization and achieve saturation binding conditions. Incubations were performed with or without unlabeled AII added in 1,000-fold excess of labeled AII. To terminate AII binding and remove the unbound AII, the GMC were washed rapidly four times with $0.4 \mathrm{ml}$ of ice-cold binding buffer. Solubilization of GMC was accomplished using $0.25 \mathrm{ml}$ of cell lysis buffer containing $0.1 \%$ SDS and $0.1 \mathrm{~N} \mathrm{NaOH}$. Specific AII binding equaled total binding ( ${ }^{125} \mathrm{I}$-AII, $0.1-10 \mathrm{nM}$; sp act, $2,000 \mathrm{Ci} / \mathrm{mmol}$ ) minus nonspecific binding (unlabeled AII). Bradford protein analysis (Bio-Rad Laboratories, Richmond, CA) was performed on 50- $\mu$ laliquots of the solubilized GMC. AII receptor binding dissociation constants $\left(K_{\mathrm{d}}\right)$ and AII receptor binding sites $\left(B_{\max }\right)$ were calculated as previously described (20-23).

Chemicals. Insulin, AII, and thapsigargin (Sigma Chemical Co., St. Louis, MO) were of the highest commercial grade available. ${ }^{125}$ I-AII was purchased from Amersham Corp. (Arlington Heights, IL).

\section{Results}

Mesangial cells contain low-conductance, $\mathrm{Ca}^{2+}$-activated $\mathrm{Cl}^{-}$ channels. Several groups have presented indirect evidence that depolarization of GMC in response to vasoactive peptides is dependent on activation of $\mathrm{Ca}^{2+}$-dependent $\mathrm{Cl}^{-}$conductance (9-11). However, identification of $\mathrm{a} \mathrm{Cl}^{-}$conductance with the 
appropriate characteristics has not been accomplished at a single channel level in GMC.

In 10 of 81 (12\%) successful cell-attached patches (pipette, $140 \mathrm{mM} \mathrm{NaCl}$ ) on cultured rat GMC grown in the presence of insulin $(100 \mathrm{mU} / \mathrm{ml})$, inward current with a unitary conductance of 2-5 picosiemens (pS) (mean $g=3.6 \pm 1.1 \mathrm{pS}$ ) was identified (Figs. 1 and 2). At resting membrane potential $\left(-\mathrm{V}_{\text {pipet }}=0 \mathrm{mV}\right), N P_{\mathrm{o}}$ (number of channels $\cdot$ open probability) was always low (mean $N P_{\mathrm{o}}=0.05 \pm 0.04$ ) in the cell-attached configuration $(n=10)$. No significant voltage dependence was detected for $N P_{\mathrm{o}}$ between $-\mathrm{V}_{\text {pipet }}$ of -80 and +80 $\mathrm{mV}$. The current-voltage (I-V) relationship revealed slight outward rectification and the reversal potential $\left(E_{\text {rev }}\right)$ was near $0 \mathrm{mV}$.

To investigate the 4-pS channel's ion selectivity, excised inside-out patches were studied (Fig. $2 B$ ). Results suggested a channel that was either selective for $\mathrm{Cl}^{-}$or nonselective for cations, $E_{\text {rev }}$ was again $\sim 0 \mathrm{mV}$ with pipettes containing 140 $\mathrm{mM} \mathrm{NaCl}$ and "cytoplasmic" bath containing $140 \mathrm{mM} \mathrm{KCl}$ (Table I, solution A) $(n=6)$. A small increase in inward current conductance $(4.2 \pm 0.2 \mathrm{pS})$ and amplitude was observed after patch excision into cytoplasmic bath solution A with $10^{-6} \mathrm{M} \mathrm{Ca}^{2+}$. Progressively replacing cytoplasmic bath $\mathrm{K}^{+}$with $\mathrm{Na}^{+}$( solutions A-C) did not shift the I-V curve, suggesting this channel was equally permeable to $\mathrm{K}^{+}$and $\mathrm{Na}^{+}$. However, raising the cytoplasmic bath $\mathrm{Cl}^{-}$concentration from $12 \mathrm{~m} \mathrm{M} \mathrm{Cl}^{-}$(solution D) to $242 \mathrm{mM} \mathrm{Cl}^{-}$(solution E) shifted the I-V curve positively $\left(E_{\text {rev }}\right.$ depolarized from -31 to +15 $\mathrm{mV}$ ). If this channel were perfectly selective for $\mathrm{Cl}^{-}$, the expected $E_{\text {rev }}$ under these ionic conditions would have shifted from -34 to $+13 \mathrm{mV}$. Thus, the selectivity of this channel is higher for $\mathrm{Cl}^{-}$than for $\mathrm{Na}^{+}$or $\mathrm{K}^{+}$. Assuming there is no significant permeability to gluconate, from Eq. 3 it can be calculated that the permeability to $\mathrm{Cl}^{-}$relative to $\mathrm{Na}^{+}$was $>50$ for this 4-pS channel.

At resting membrane potential, acute application of 100 $\mathrm{nM}$ AII to the extracellular bath outside the cell-attached patch pipette abruptly increased mean $N P_{\mathrm{o}}(0.28 \pm 0.13)$ for the 4-pS $\mathrm{Cl}^{-}$channel $(n=5)$. Fig. 3 is a single-channel record showing $\mathrm{Cl}^{-}$channel activation by AII. Comparing data obtained from each patch before adding AII, the average change in $N P_{\mathrm{o}}$ after AII was significant by paired $t$ test (see Methods) (Fig. 4). $\mathrm{Cl}^{-}$

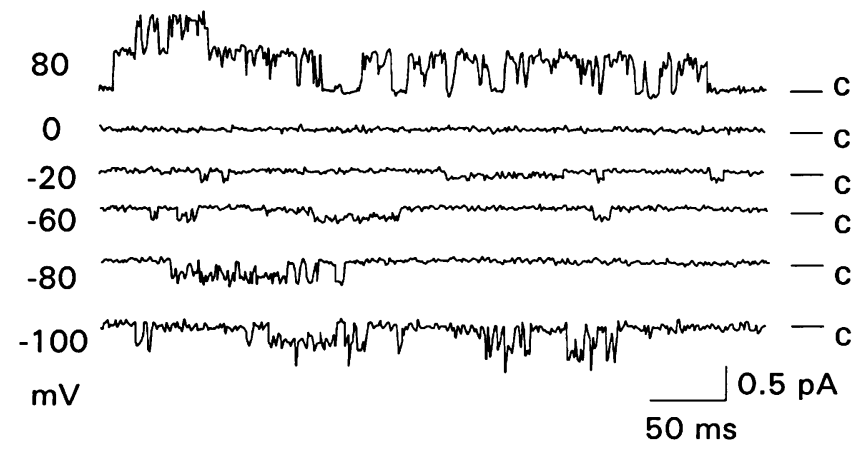

Figure 1. Single low-conductance $\mathrm{Cl}^{-}$channel events. Cell-attached patch depicts inward current (outward $\mathrm{Cl}^{-}$movement) as downward deflections. Horizontal bars mark the zero current level $(C$, closed state). Voltage $(\mathrm{mV})$ represents the applied patch pipette voltage $\left(-V_{\text {pipet }}\right)$ displacement away from resting membrane potential (see Methods). Each trace was recorded at a corner frequency ( $\mathrm{Fc}$ ) of 1 $\mathrm{KHz}$, sampled at $5 \mathrm{KHz}(200 \mu \mathrm{s} /$ point $)$, and depicted without software filtering.

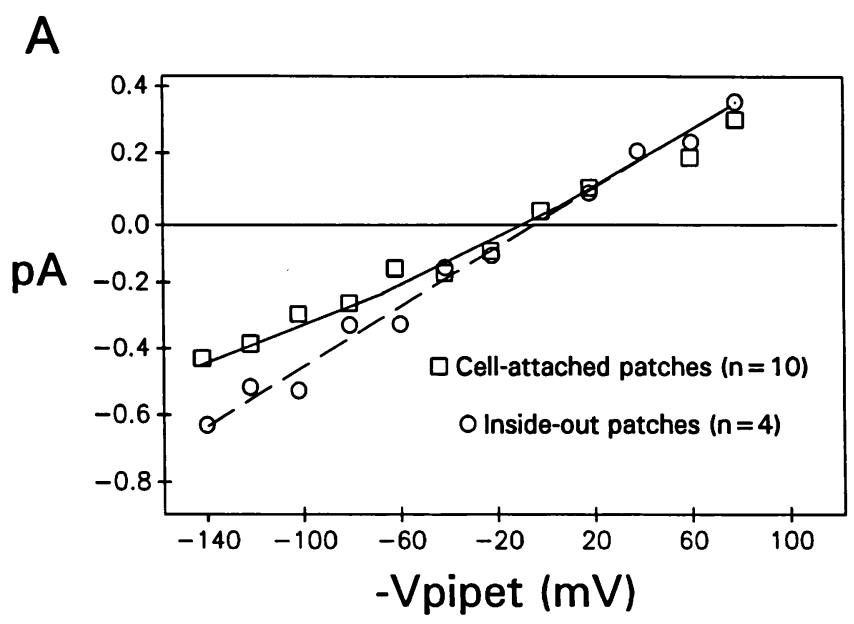

B

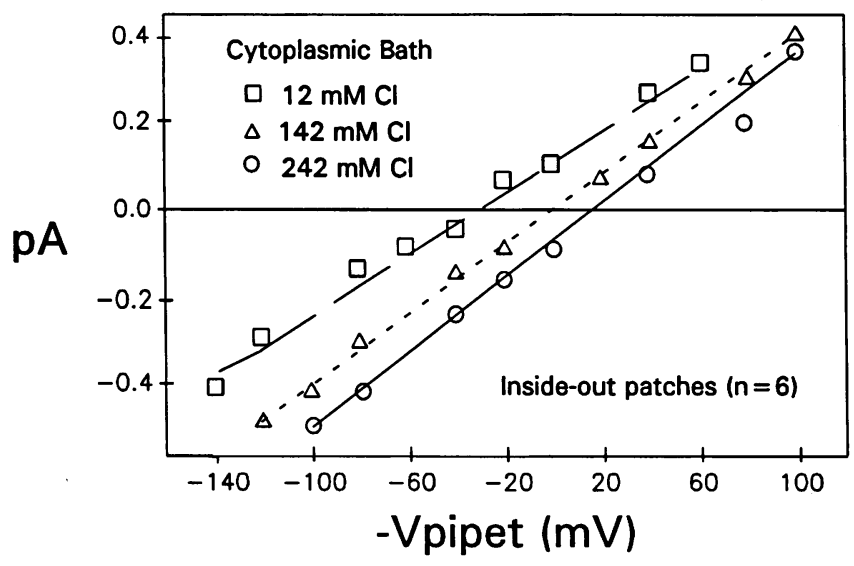

Figure 2. Current-voltage (I-V) relationship for low conductance $\mathrm{Cl}^{-}$ channel. $(A)$ Cell-attached patches ( squares) and inside-out patches excised into a $140-\mathrm{mM} \mathrm{KCl}, 10^{-7} \mathrm{M} \mathrm{CaCl}_{2}$ (solution A; circles) cytoplasmic bath reveal slight outward rectification. Unit conductance was calculated from the I-V curve slope near resting membrane potential $\left(-\mathrm{V}_{\text {pipet }}=0 \mathrm{mV}\right) .(B)$ Cytoplasmic ion replacement experiments (mean current amplitude for six inside-out patches): I-V curves with cytoplasmic bath $12 \mathrm{mM} \mathrm{Cl}^{-}$(solution D; squares), 142 $\mathrm{mM} \mathrm{Cl}^{-}$(solution A; triangles), and $242 \mathrm{mM} \mathrm{Cl}^{-}$(solution E; circles) show reversal potentials $\left(E_{\mathrm{rev}}\right)$, indicating a $P_{\mathrm{Cl}} / P_{\mathrm{Na}}$ ratio $>50: 1$. Cytoplasmic $\mathrm{Ca}^{2+}$ was $10^{-6} \mathrm{M}$ for all ion replacement experiments.

Table I. Solution Composition for Patch Clamp Experiments

\begin{tabular}{lcccccc}
\hline \multicolumn{1}{c}{ Solution } & A & B & C & D & E & F \\
\hline $\mathrm{NaCl}$ & 5 & 50 & 95 & 10 & 240 & 14 \\
$\mathrm{KCl}$ & 140 & 95 & 50 & 0 & 0 & 0 \\
$\mathrm{MgCl}_{2}$ & 1 & 1 & 1 & 1 & 1 & 1 \\
$\mathrm{CaCl}_{2}$ & $10^{-8}-10^{-4}$ & $10^{-6}$ & $10^{-6}$ & $10^{-6}$ & $10^{-6}$ & $10^{-6}$ \\
EGTA & 2 & 2 & 2 & 2 & 2 & 0 \\
$\mathrm{Na}$ gluconate & 0 & 0 & 0 & 124 & 0 & 0 \\
Mannitol & 0 & 0 & 0 & 0 & 0 & 240 \\
Hepes & 10 & 10 & 10 & 10 & 10 & 10 \\
pH & 7.4 & 7.4 & 7.4 & 7.4 & 7.4 & 7.4 \\
& & & & & &
\end{tabular}

Data shown are millimolar concentrations, except for $\mathrm{CaCl}_{2}$ which is reported as the final free $\mathrm{Ca}^{2+}$ molar concentration. $\mathrm{NaCl}$ and $\mathrm{KCl}$ are final concentrations after titration of $\mathrm{pH}$ with $\mathrm{NaOH}$ or $\mathrm{KOH}$. 


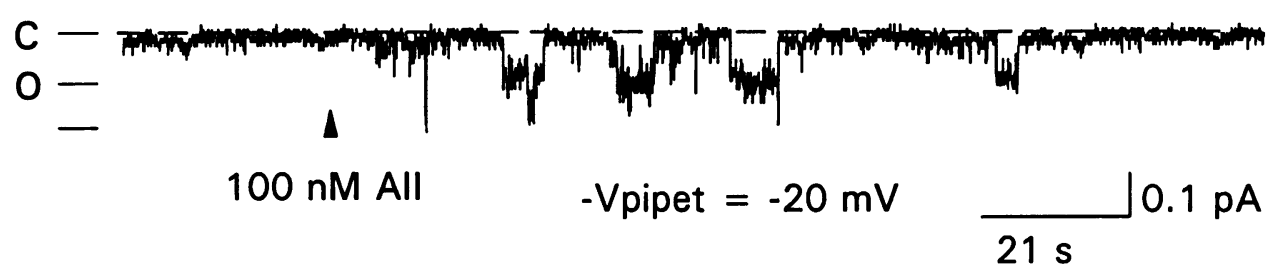

Figure 3. Low conductance $\mathrm{Cl}^{-}$channel activation by AII. $100 \mathrm{nM}$ AII was slowly added to the extracellular bath outside the cell-attached patch pipette over $15 \mathrm{~s}$ to prevent disruption of the membrane seal. Recording of 4-pS Cl${ }^{-}$ channel at $-V_{\text {pipet }}=-20 \mathrm{mV}$ depicts activation of inward current events within seconds of AII exposure. Fc $=1$ $\mathrm{KHz}$; sampling $=5 \mathrm{KHz}$; and software filtering $=400 \mathrm{~Hz}$. channel activation was also observed at AII doses of $1 \mathrm{nM}$ ( $n$ $=4)$ and $10 \mathrm{nM}(n=4)$.

Hydrolysis of mesangial cell membrane phospholipids, initiated by vasoactive peptides including AII, is associated with release of inositol-1,4,5-trisphosphate $\left(\mathrm{IP}_{3}\right)$-sensitive intracellular $\mathrm{Ca}^{2+}$ pools $(1,24)$. This effect can be mimicked by thapsigargin, which releases $\mathrm{Ca}^{2+}$ from intracellular pools without hydrolysis of inositol polyphosphates $(16,25,26)$. Acute exposure to $0.25 \mu \mathrm{M}$ thapsigargin in the extracellular bath also increased $\mathrm{Cl}^{-}$channel activity $(n=4)$ (Fig. 4). The average change in $N P_{\mathrm{o}}$ was again significant. In the excised inside-out patch configuration, directly raising the free "cytoplasmic" $\mathrm{Ca}^{2+}$ concentration from $10^{-8}$ to $10^{-4} \mathrm{M}$ increased $P_{\mathrm{o}}$ by $\sim 10$ fold and confirmed this was a $\mathrm{Ca}^{2+}$-dependent $\mathrm{Cl}^{-}$channel ( $n$ =6) (Fig. 5, triangles).

Mesangial cells contain $\mathrm{Ca}^{2+}$-activated nonselective cation channels. A second channel type with a unitary conductance of 25-29 pS (mean $g=27.4 \pm 1.9 \mathrm{pS}$ ) and a linear I-V relationship was identified in 16 of $81(20 \%)$ successful cell-attached

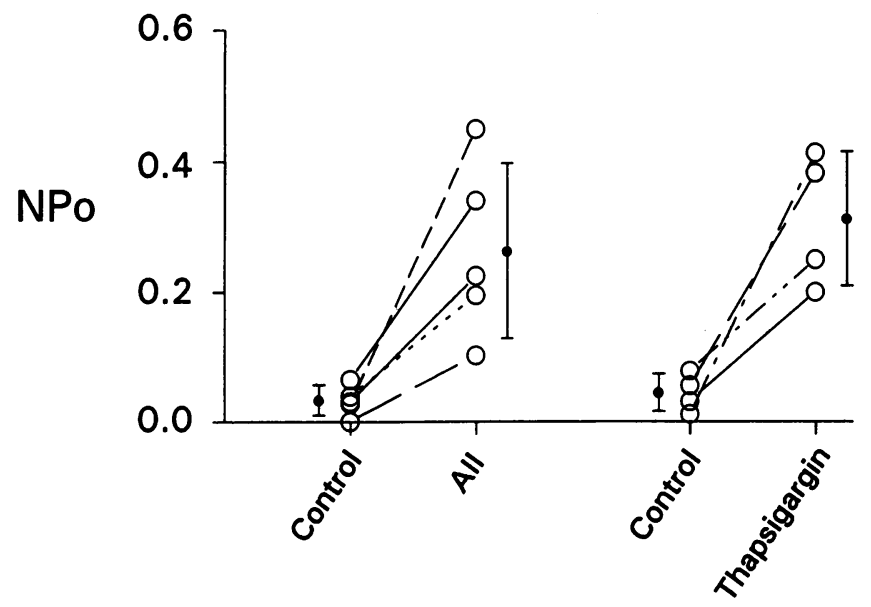

Figure 4. Activation of $\mathrm{Cl}^{-}$channels by AII is mimicked by release of intracellular $\mathrm{Ca}^{2+}$ stores. (Left) $\mathrm{Cl}^{-}$channel activity, $N P_{\mathrm{o}}$ ( number of channels $\times$ the open probability), is depicted before and after 100 $\mathrm{nM}$ AII exposure for cell-attached patches at $-\mathrm{V}_{\text {pipet }}=-20 \mathrm{mV}$. Mean $N P_{\mathrm{o}}$ increased from $0.033 \pm 0.023$ to $0.28 \pm 0.13(n=5)$. (Right) $\mathrm{Cl}^{-}$channel activity is depicted before and after $0.25 \mu \mathrm{M}$ thapsigargin exposure for cell-attached patches at $-\mathrm{V}_{\text {pipet }}=-20 \mathrm{mV}$. Mean $N P_{\circ}$ increased from $0.045 \pm 0.029$ to $0.31 \pm 0.10(n=4)$. Control $N P_{\mathrm{o}}$ was calculated for the 3-min recording period just before AII or thapsigargin exposure. AII or thapsigargin were added to the extracellular bath outside the cell-attached patch pipettes over $15 \mathrm{~s}$ to prevent disruption of the membrane seal. $N P_{0}$ 's were then calculated for 1-2min recordings immediately after exposure. Symbols connected by lines represent relative change in channel activity for the same cellattached patch. patches (pipette, $140 \mathrm{mM} \mathrm{NaCl}$ ) on rat GMC grown in the presence of insulin ( $100 \mathrm{mU} / \mathrm{ml}$ ) (Figs. 6 and 7). In the cell-attached configuration, this channel was rarely open at resting membrane potential (mean $N P_{\mathrm{o}}=0.03 \pm 0.05$ ). $N P_{\mathrm{o}}$ was insensitive to either membrane depolarization or hyperpolarization $\left(-\mathrm{V}_{\text {pipet }}\right.$ between -120 and $\left.+120 \mathrm{mV}\right)$. The $E_{\text {rev }}$ in the cell-attached configuration was close to $0 \mathrm{mV}$.

When excised inside-out patches (pipette, $140 \mathrm{mM} \mathrm{NaCl}$ ) were exposed to a cytoplasmic bath containing $140 \mathrm{mM} \mathrm{KCl}$ (solution A), the $E_{\text {rev }}$ was also very near $0 \mathrm{mV}(n=5)$ (Fig. 7 $B)$. Unitary conductance did not change with patch excision nor did $E_{\text {rev }}$ change appreciably with progressive replacement of $\mathrm{K}^{+}$for $\mathrm{Na}^{+}$in the cytoplasmic bath (solutions A-C). In anion exchange experiments, the cytoplasmic bath was switched from $147 \mathrm{mM} \mathrm{Cl}^{-}$(solution A) to $124 \mathrm{mM}$ gluconate (solution D), but there was little change in $E_{\text {rev }}(+1.2 \pm 2.0)$. However, exchanging both intracellular cations and anions for the nondiffusible osmole, mannitol (solution F), shifted the $E_{\text {rev }}(+43.1 \pm 4.2 \mathrm{mV})$ toward $E_{\mathrm{Na}}(+58 \mathrm{mV})$. The last two experiments indicate that $P_{\mathrm{Cl}} / P_{\mathrm{Na}}$ for this channel is only $\sim 0.1: 1$. When monovalent cations were replaced with divalent cations in the pipette solution (pipette, $110 \mathrm{mM} \mathrm{CaCl}_{2}, 10$ $\mathrm{mM}$ glucose, $10 \mathrm{mM}$ Hepes, $\mathrm{pH}$ 7.4), inward current channel events (ie., $\mathrm{Ca}^{2+}$ influx) could not be distinguished $(n=4)$. In contrast to the 4-pS Cl${ }^{-}$channel, cytoplasmic ion substitution

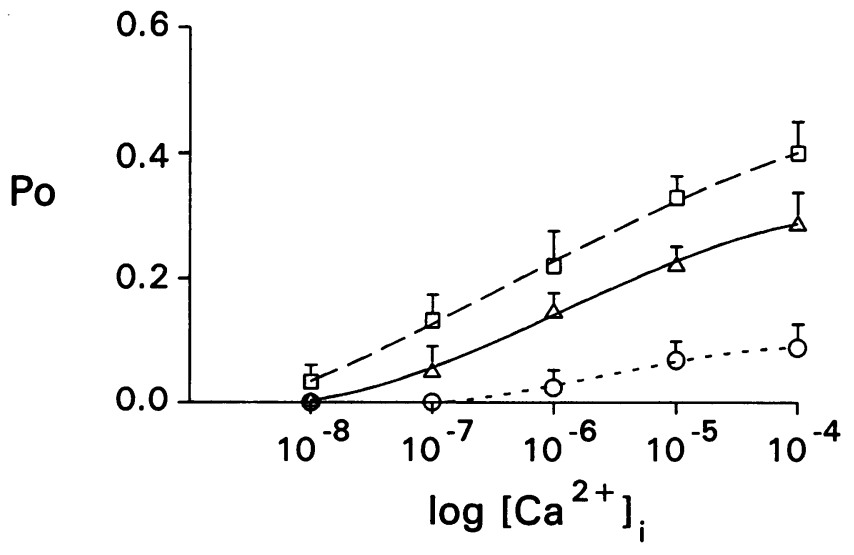

Figure 5. Intracellular $\mathrm{Ca}^{2+}$ activates $\mathrm{Cl}^{-}$channel. $\mathrm{Cl}^{-}$channel activity (mean $P_{\mathrm{o}}$ 's from six inside-out patches) is plotted with increasing free $\mathrm{Ca}^{2+}$ concentrations $\left(10^{-8}-10^{-4} \mathrm{M}\right.$; see Methods) bathing the cytoplasmic surface of the excised patch membrane. Plots are for cultured GMC grown with insulin (triangles; $n=6$ ), insulin-deficient GMC cultures (circles; $n=3$ ), and insulin-deficient GMC cultures after acute insulin exposure (squares; $n=8$ ). Since the $\mathrm{Ca}^{2+}$ activation curves were similar for low- and high-dose acute insulin exposure, the data are combined. 


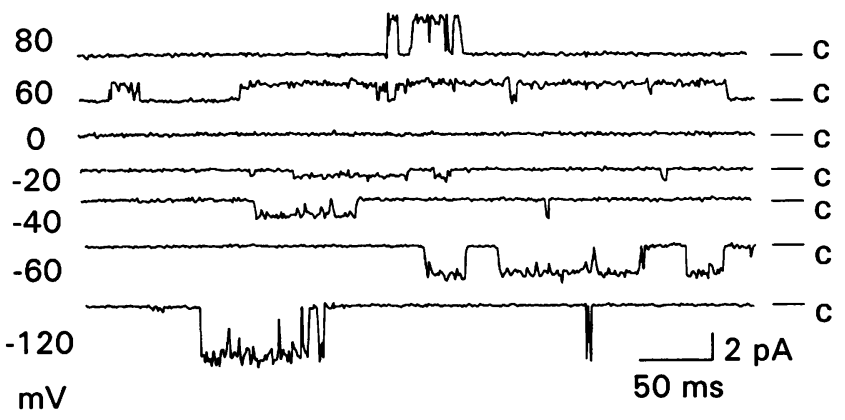

Figure 6. Single nonselective channel events. Cell-attached recording shows inward current events at $-\mathrm{V}_{\text {pipet }}<0 \mathrm{mV}$. Fc $=1 \mathrm{KHz}$; sampling $=5 \mathrm{KHz}$; and no software filtering.

experiments revealed that the 27-pS channel was nonselective for $\mathrm{Na}^{+}$over $\mathrm{K}^{+}$, but relatively impermeable to $\mathrm{Cl}^{-}$.

Matsunaga et al. (15) have previously described a 25-pS

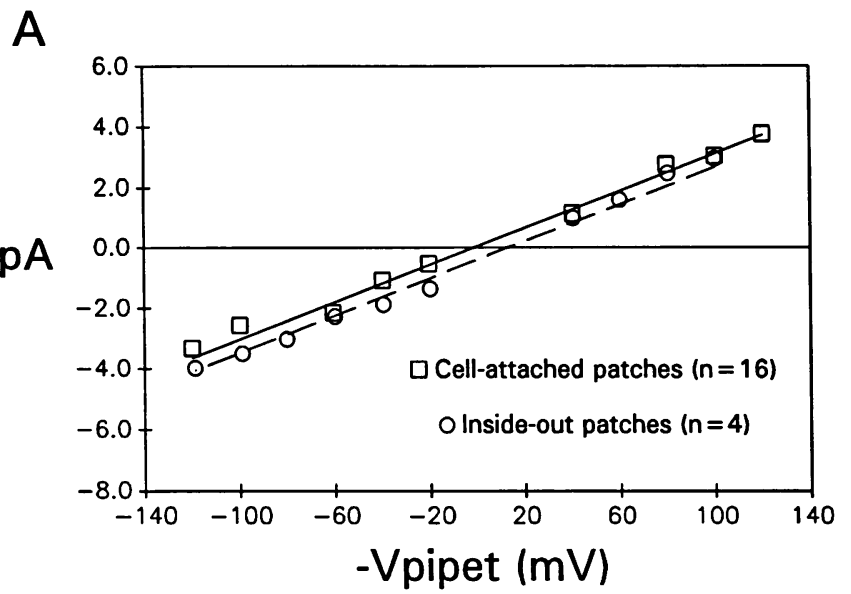

B

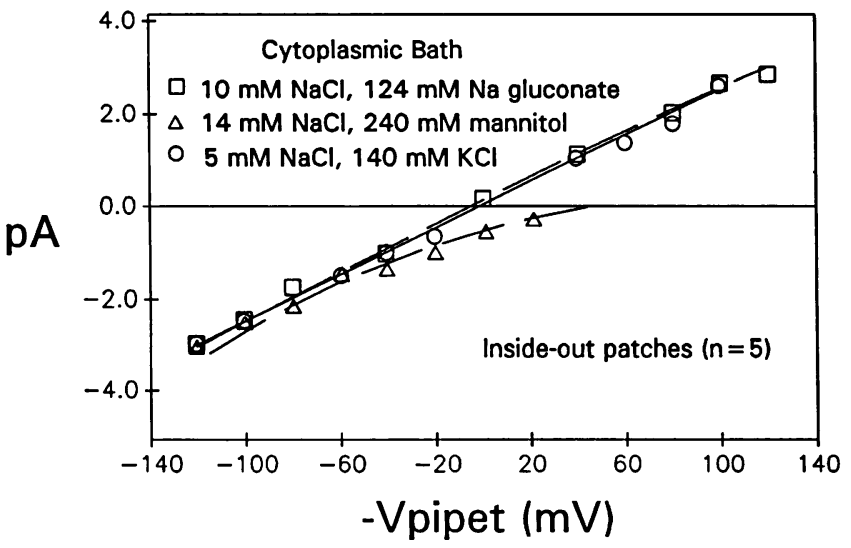

Figure 7. I-V relationship for nonselective cation channel. $(A)$ Cellattached (squares) and inside-out configurations with $140 \mathrm{mM}$ bath $\mathrm{KCl}$ (solution A; circles) reveal a channel that is relatively nonselective for $\mathrm{Na}^{+}$over $\mathrm{K}^{+}$ions $\left(E_{\text {rev }} \sim 0 \mathrm{mV}\right)$. Linear regression analysis reveals a unitary conductance of $27.4 \pm 1.9 \mathrm{pS}$. (B) Cytoplasmic ion replacement experiments (mean current amplitude for five inside-out patches): $\mathrm{I}-\mathrm{V}$ curve with cytoplasmic bath containing $5 \mathrm{mM} \mathrm{NaCl} /$ $140 \mathrm{mM} \mathrm{KCl}$ (solution A; circles) is depicted. Replacement of bath KCL with $124 \mathrm{mM}$ Na gluconate (solution D; squares) did not significantly alter $E_{\text {rev }}$. Replacement with $240 \mathrm{mM}$ mannitol (solution F; triangles) shifted $E_{\text {rev }}$ positively. Calculated $P_{\mathrm{Cl}} / P_{\mathrm{Na}} \sim 0.1: 1$. Cytoplasmic $\mathrm{Ca}^{2+}$ was $10^{-6} \mathrm{M}$ for all ion replacement experiments. nonselective cation channel (NSCC) in cultured rat GMC that was activated by vasoactive peptides (vasopressin or AII), or by raising cytoplasmic $\mathrm{Ca}^{2+}$. Similarly, when we exposed cultured GMC to AII ( $100 \mathrm{nM}$ ) in the extracellular bath, a significant increase in NSCC activity (mean $N P_{0}=0.20 \pm 0.12$ ) was observed in cell-attached patches $(n=6)$ (Fig. 8). NSCC activation was also observed at AII doses of $1 \mathrm{nM}(n=3)$ and 10 $\mathrm{nM}(n=5)$. Releasing intracellular $\mathrm{Ca}^{2+}$ pools with $0.25 \mu \mathrm{M}$ thapsigargin also caused NSCC activation (mean $N P_{\text {o }}$ $=0.20 \pm 0.06)$ in cell-attached patches $(n=4)$. Confirming the $\mathrm{Ca}^{2+}$ dependency of this NSCC, direct exposure of the cytoplasmic surface of inside-out patches to progressively higher $\mathrm{Ca}^{2+}$ concentrations $\left(10^{-8}-10^{-4} \mathrm{M}\right)$ also increased $P_{\mathrm{o}}(n=5)$ (Fig. 9, triangles).

$\mathrm{Cl}^{-}$and nonselective cation channel activation is dependent on exogenous insulin. In cultured rat GMC grown in the absence of insulin (insulin-deficient GMC cultures), the 4-pS Cl${ }^{-}$ channel was observed in only $4 \%(3 / 74)$ of cell-attached patches. Moreover, there was no stimulation of channel activity in 3 patches with or 20 patches without baseline $\mathrm{Cl}^{-}$channel activity when $100 \mathrm{nM}$ AII was added to the extracellular bath. $0.25 \mu \mathrm{M}$ thapsigargin also failed to activate the $\mathrm{Cl}^{-}$channel.

Insulin-deficient GMC cultures were then exposed to various levels of insulin $(1 \mu \mathrm{U} / \mathrm{ml}, 10 \mu \mathrm{U} / \mathrm{ml}, 100 \mu \mathrm{U} / \mathrm{ml}$, and $100 \mathrm{mU} / \mathrm{ml}$ ) for $15 \mathrm{~min}$ before patching. Acute exposure to insulin concentrations of 1 or $10 \mu \mathrm{U} / \mathrm{ml}$ (low dose) did not change $\mathrm{Cl}^{-}$channel activity in cell-attached patches when compared with insulin-deficient GMC cultures $(n=7)$ (Fig. 10 , right ). However, after acute insulin exposure, $100 \mathrm{nM}$ AII stimulated $\mathrm{Cl}^{-}$channel activity in six of seven patches. When compared with insulin-deficient cultures, acute exposure to $100 \mu \mathrm{U} / \mathrm{ml}$ or $100 \mathrm{mU} / \mathrm{ml}$ insulin (high dose) alone increased baseline inward current $N P_{\mathrm{o}}$ and amplitude for the 4-pS $\mathrm{Cl}^{-}$ channel $(n=10)$ (Fig. 10, left). In six experiments, high-resistance patch seals were stable enough to measure the stimulatory effects of high-dose insulin on the 4- $\mathrm{pS} \mathrm{Cl}^{-}$channel in the same patch for $>15 \mathrm{~min}$ (Fig. 11). Within $5 \mathrm{~min}$ of applying

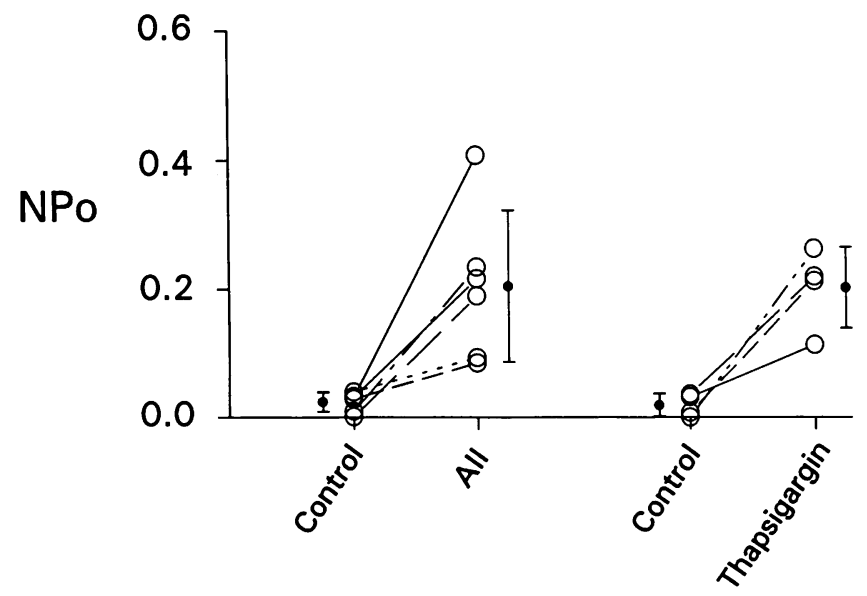

Figure 8. Activation of NSCC by AII is mimicked by release of intracellular $\mathrm{Ca}^{2+}$ stores. ( $L e f t$ ) NSCC activity: $N P_{\mathrm{o}}$ is depicted before and after $100 \mathrm{nM}$ AII exposure for cell-attached patches at $-\mathrm{V}_{\text {pipet }}$ $=-20 \mathrm{mV}$. Mean $N P_{\mathrm{o}}$ increased from $0.024 \pm 0.015$ to $0.20 \pm 0.12(n$ $=6)$. (Right) NSCC activity: $N P_{\mathrm{o}}$ is depicted before and after 0.25 $\mu \mathrm{M}$ thapsigargin exposure for cell-attached patches at $-\mathrm{V}_{\text {pipet }}=-20$ $\mathrm{mV}$. Mean $N P_{\mathrm{o}}$ increased from $0.019 \pm 0.018$ to $0.20 \pm 0.06(n=4)$. $N P_{\mathrm{o}}$ 's were calculated as in Fig. 4. 


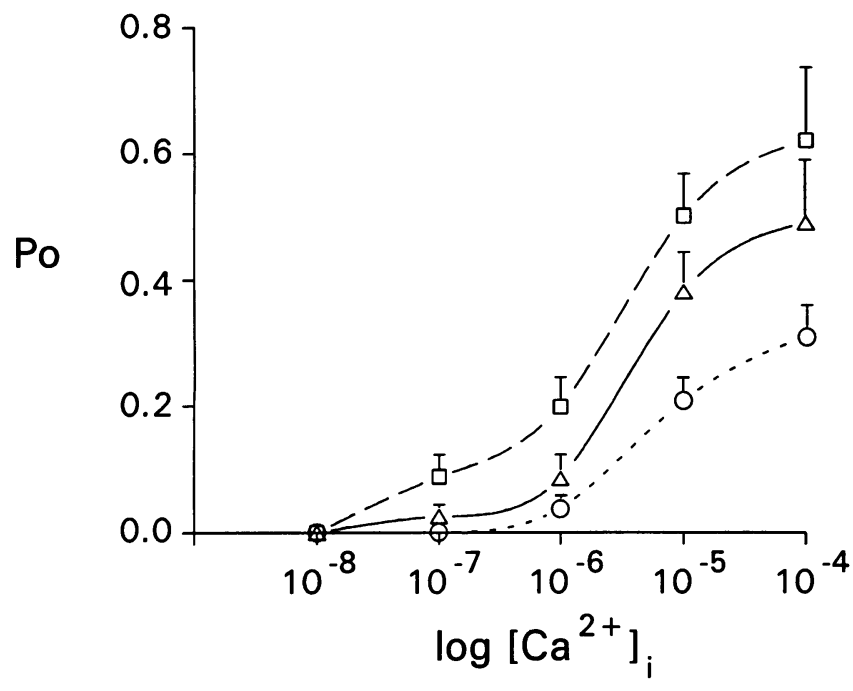

Figure 9. Intracellular $\mathrm{Ca}^{2+}$ activates NSCC. NSCC activity (mean $P_{\mathrm{o}}$ 's from six inside-out patches) is plotted with increasing free $\mathrm{Ca}^{2+}$ concentrations $\left(10^{-8}-10^{-4} \mathrm{M}\right.$; see Methods) bathing the cytoplasmic surface of the excised patch membrane. Plots represent cultured GMC grown in insulin (triangles; $n=5$ ) and insulin-deficient GMC cultures (circles; $n=4$ ), and insulin-deficient GMC cultures exposed to high- or low-dose acute insulin ( squares; $n=8$ ).

$100 \mu \mathrm{U} / \mathrm{ml}$ insulin to the extracellular bath, an increase in $\mathrm{Cl}^{-}$ channel $N P_{\mathrm{o}}$ was observed. An additional stimulation of $\mathrm{Cl}^{-}$ channel activity was observed within seconds of adding 100

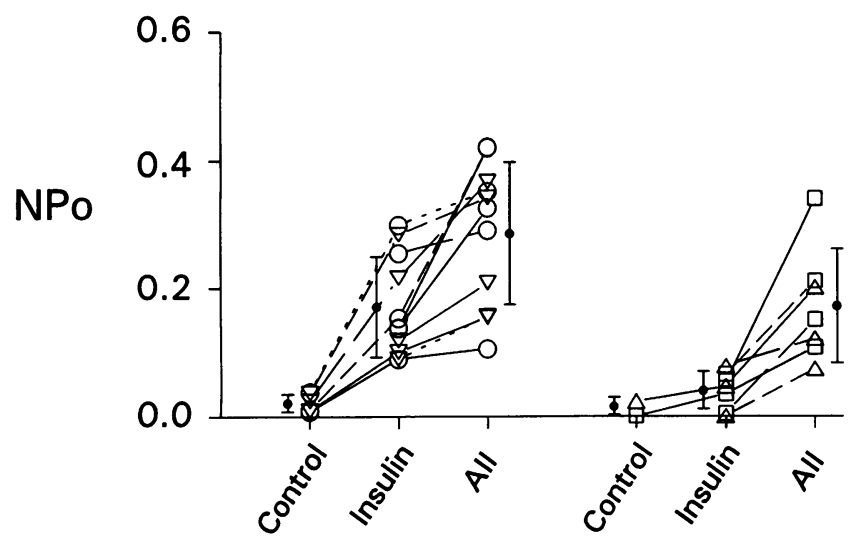

Figure 10. Effect of acute insulin exposure on $\mathrm{Cl}^{-}$channel. Cultured GMC were grown in the absence of insulin and then acutely exposed to exogenous insulin at various concentrations. ( Left $)$ High-dose insulin exposure (inverted triangles, $100 \mu \mathrm{U} / \mathrm{ml}$ insulin; circles, 100 $\mathrm{mU} / \mathrm{ml}$ insulin ). $\mathrm{Cl}^{-}$channel activity: $N P_{\mathrm{o}}$ is depicted before and 15 min after high-dose insulin exposure for cell-attached patches at $-\mathrm{V}_{\text {pipet }}=-20 \mathrm{mV}$. Mean $N P_{\mathrm{o}}$ increased from $0.021 \pm 0.014$ to $0.17 \pm 0.08$. After $15 \mathrm{~min}$ of high-dose insulin exposure, $100 \mathrm{nM}$ AII was added to the extracellular bath. An additional increase in mean $N P_{\text {o }}$ to $0.29 \pm 0.11$ was observed (Right) Low-dose insulin exposure (triangles, $10 \mu \mathrm{U} / \mathrm{ml}$ insulin; squares, $1 \mu \mathrm{U} / \mathrm{ml}$ insulin). Scant $\mathrm{Cl}^{-}$ channel activity is observed before or $15 \mathrm{~min}$ after low-dose insulin exposure for cell-attached patches at $-\mathrm{V}_{\text {pipet }}=-20 \mathrm{mV}$. $N P_{\mathrm{o}}$ was unaffected by 15 -min exposure to low-dose insulin, but subsequent addition of $100 \mathrm{nM}$ AII to the extracellular bath increased mean $N P_{\mathrm{o}}$ to $0.17 \pm 0.09$. Control $N P_{\mathrm{o}}$ was calculated for the 3-min recording period just before acute insulin exposure. $N P_{\mathrm{o}}$ 's were then calculated for 1-2 min of recording $15 \mathrm{~min}$ after insulin exposure and immediately after AII exposure. Symbols connected by lines represent relative change in channel activity for the same cell-attached patch.

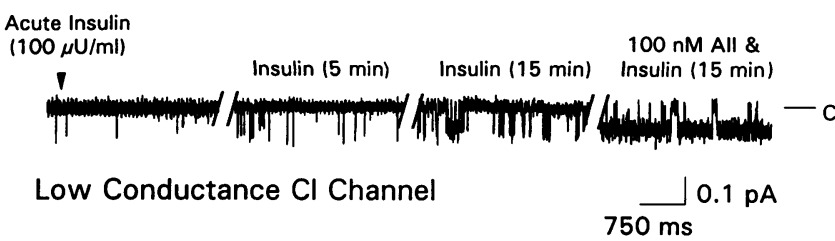

Figure 11. Effect of high-dose insulin exposure on $\mathrm{Cl}^{-}$channel. Single channel recordings from the same cell-attached patch at $-\mathrm{V}_{\text {pipet }}$ $=-20 \mathrm{mV}$. Progressive increase in $\mathrm{Cl}^{-}$channel activity is observed after 5- and 15-min exposure to $100 \mu \mathrm{U} / \mathrm{ml}$ insulin. A further increase in channel activity is seen with the subsequent addition of 100 $\mathrm{nM}$ AII. Fc $=1 \mathrm{KHz}$; sampling $=5 \mathrm{KHz}$; and no software filtering.

nM AII. Restoration of $\mathrm{Cl}^{-}$channel sensitivity to AII in cell-attached patches was observed with all acute insulin concentrations $(1 \mu \mathrm{U} / \mathrm{ml}, 10 \mu \mathrm{U} / \mathrm{ml}, 100 \mu \mathrm{U} / \mathrm{ml}$, and $100 \mathrm{mU} / \mathrm{ml})$.

The $\mathrm{Ca}^{2+}$ activation curve for the 4-pS Cl${ }^{-}$channel in excised patches shifted to the left when comparing cultured GMC grown with insulin (Fig. 5, triangles; $n=6$ ) with insulin-deficient GMC cultures (Fig. 5, circles; $n=3$ ). A further leftward shift was observed for excised patches from insulin-deficient GMC cultures exposed to insulin acutely (Fig. 5, squares; $n$ $=8$ ). Since the $\mathrm{Ca}^{2+}$ activation curves were similar for lowand high-dose acute insulin exposure, the data are combined in Fig. 5.

The 27-pS NSCC was observed in 11 of $74(15 \%)$ cell-attached patches obtained in insulin-deficient GMC cultures. Usually closed at $-\mathrm{V}_{\text {pipet }}=0 \mathrm{mV}, N P_{\mathrm{o}}$ for this NSCC was not altered by adding $100 \mathrm{nM}$ AII and $0.25 \mu \mathrm{M}$ thapsigargin in seven of seven cell-attached patches. NSCC $N P_{\mathrm{o}}$ increased in cell-attached patches obtained on insulin-deficient GMC cultures exposed to high-dose insulin $(100 \mu \mathrm{U} / \mathrm{ml}$ or $100 \mathrm{mU} /$ $\mathrm{ml}$ ) for $15 \mathrm{~min}$ before study $(n=9)$ (Fig. 12, left). GMC exposure to low-dose insulin $(1 \mu \mathrm{U} / \mathrm{ml}$ or $10 \mu \mathrm{U} / \mathrm{ml})$ for 15 min did not increase $N P_{\mathrm{o}}$, but did restore the stimulatory response of NSCC to subsequent application of $100 \mathrm{nM}$ AII in seven patches (Fig. 12, right). Fig. 13 is a single channel record depicting restoration of AII responsiveness by acute exposure to $10 \mu \mathrm{U} / \mathrm{ml}$ insulin.

In the inside-out configuration, $\mathrm{Ca}^{2+}$ activation curves for the 27-pS NSCC also shifted to the left when comparing cultured GMC grown in insulin (Fig. 9, triangles; $n=5$ ) with insulin-deficient GMC cultures (Fig. 9, circles; $n=4$ ). Acute exposure of insulin-deficient GMC cultures to high- or lowdose acute insulin again resulted in a further leftward shift in the $\mathrm{Ca}^{2+}$ activation curve (Fig. 9, squares; $n=8$ ). Restoration of NSCC sensitivity to activation by AII in cell-attached patches or cytoplasmic $\mathrm{Ca}^{2+}$ in excised patches was seen with all acute insulin concentrations $(1 \mu \mathrm{U} / \mathrm{ml}, 10 \mu \mathrm{U} / \mathrm{ml}, 100 \mu \mathrm{U} /$ $\mathrm{ml}$, and $100 \mathrm{mU} / \mathrm{ml}$ ).

Chronic, but not acute insulin exposure increases AII receptor density. Since exogenous insulin exposure could conceivably affect AII ligand-receptor interactions, AII receptor binding studies were performed. Fig. 14 shows that AII binds to rat glomerular mesangial cells in a saturable manner when measured at $4^{\circ} \mathrm{C}$ to prevent AII receptor internalization. For cultured rat GMC grown in the absence of insulin, the number of binding sites $\left(B_{\max }\right)$ was $2.44 \pm 0.58 \mathrm{fmol} / \mathrm{mg}$ protein and the apparent binding dissociation constant $\left(K_{\mathrm{d}}\right)$ was $3.02 \pm 2.01$ $\mathrm{nM}$. Acute exposure of insulin-deficient GMC cultures to lowdose $(10 \mu \mathrm{U} / \mathrm{ml})$ or high-dose $(100 \mathrm{mU} / \mathrm{ml})$ insulin for 15 


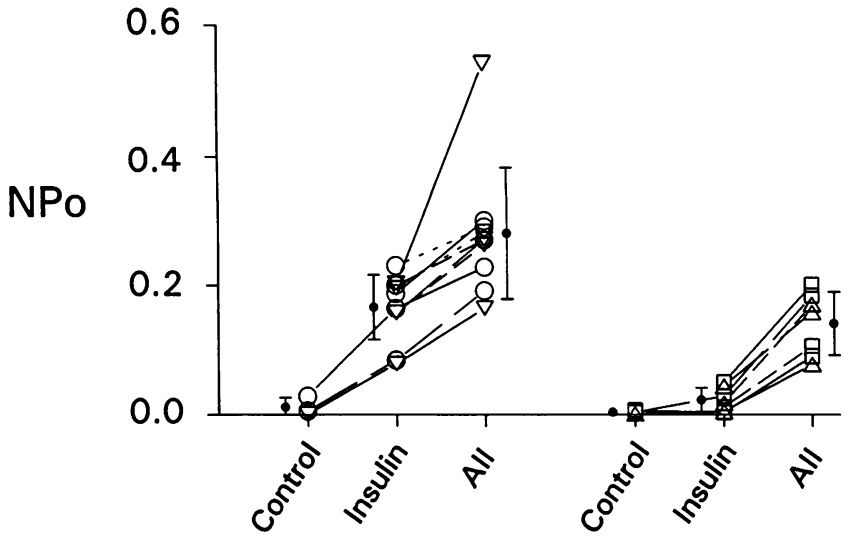

Figure 12. Effect of acute insulin exposure on NSCC. Cultured GMC were grown in the absence of insulin and then acutely exposed to exogenous insulin. (Left) High-dose insulin exposure (inverted triangles, $100 \mu \mathrm{U} / \mathrm{ml}$ insulin; circles, $100 \mathrm{mU} / \mathrm{ml}$ insulin ). NSCC activity: $N P_{\mathrm{o}}$ is depicted before and $15 \mathrm{~min}$ after high-dose insulin exposure for cell-attached patches at $-\mathrm{V}_{\text {pipet }}=-20 \mathrm{mV}$. Mean $N P_{\mathrm{o}}$ increased from $0.011 \pm 0.014$ to $0.18 \pm 0.05$. After $15 \mathrm{~min}$ of high-dose insulin exposure, $100 \mathrm{nM}$ AII addition increased mean $N P_{\mathrm{o}}$ to $0.28 \pm 0.10$. (Right) Low-dose insulin exposure (triangles, $10 \mu \mathrm{U} / \mathrm{ml}$ insulin; squares, $1 \mu \mathrm{U} / \mathrm{ml}$ insulin). Before and $15 \mathrm{~min}$ after low-dose insulin exposure, NSCC activity was negligible for cell-attached patches at $-V_{\text {pipet }}=-20 \mathrm{mV}$. After $15 \mathrm{~min}$ of low-dose insulin exposure, subsequent addition of $100 \mathrm{nM}$ AII increased mean $N P_{\mathrm{o}}$ to $0.14 \pm 0.05 . N P_{\mathrm{o}}$ was measured as in Fig. 10 .

min before AII binding resulted in $B_{\max }$ values of $4.43 \pm 3.28$ and $4.12 \pm 2.24 \mathrm{fmol} / \mathrm{mg}$ protein and $K_{\mathrm{d}}$ values of $1.37 \pm 2.45$ and $1.18 \pm 2.77 \mathrm{nM}$, respectively. The latter $B_{\max }$ and $K_{\mathrm{d}}$ values were not significantly different from values from insulin-deficient GMC cultures. When GMC were chronically exposed to $100 \mathrm{mU} / \mathrm{ml}$ insulin in the growth medium, there was a marked increase in AII binding, due to a significant increase in $B_{\max }$ $(17.4 \pm 2.6 \mathrm{fmol} / \mathrm{mg}$ protein $)$, while $K_{\mathrm{d}}(3.11 \pm 1.81 \mathrm{nM})$ was not significantly different from insulin-deficient GMC cultures.

\section{Discussion}

The measured membrane potential of glomerular mesangial cells or phenotypically similar vascular smooth muscle cells ranges from -40 to $-55 \mathrm{mV}(1,6)$, the same physiologic range in which $\mathrm{Ca}^{2+}$ channels are strongly voltage dependent in contractile vascular smooth muscle cells. Evidence indicates that GMC contraction also depends on the activation of voltage-de-

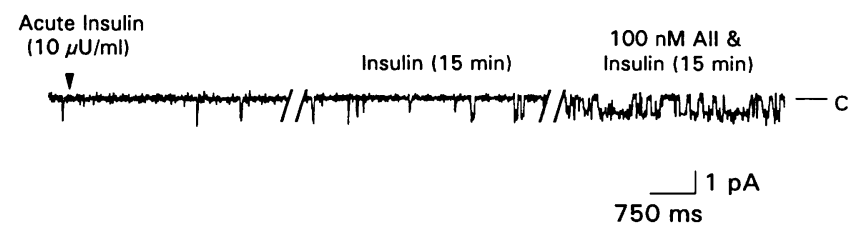

Figure 13. Effect of low-dose insulin exposure on NSCC. Singlechannel recordings from the same cell-attached patch at $-\mathrm{V}_{\text {pipet }}$ $=-20 \mathrm{mV}$. No change in NSCC activity is observed after 15-min exposure to $10 \mu \mathrm{U} / \mathrm{ml}$ insulin, but channel activity is stimulated by the subsequent addition of $100 \mathrm{nM}$ AII. Fc $=1 \mathrm{KHz}$, sampling $=5 \mathrm{KHz}$; and no software filtering.

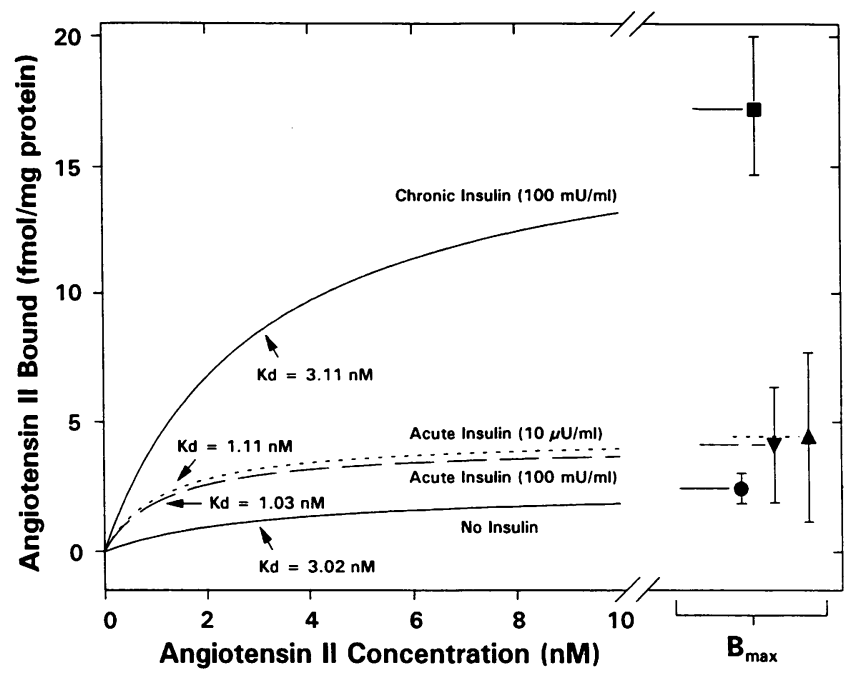

Figure 14. AII receptor binding assays. Specific binding of ${ }^{125}$ I AII to rat GMC at equilibrium ( $90 \mathrm{~min}$ ) as a function of ${ }^{125}$ I-AII concentration under different exogenous insulin exposure conditions. Plots are for cultured GMC grown with $100 \mathrm{mU} / \mathrm{ml}$ insulin (square), insulin-deficient GMC cultures (circle), and insulin-deficient GMC cultures after acute low-dose ( $10 \mu \mathrm{U} / \mathrm{ml}$; triangle) or high-dose ( 100 $\mathrm{mU} / \mathrm{ml}$; inverted triangle) insulin exposure. The binding affinity constants $\left(K_{d}\right)$ are marked by arrows (left $)$, and the number of binding sites $\left(B_{\max }\right)$ are shown on the right.

pendent $\mathrm{Ca}^{2+}$ channels (2-5). In cultured rat GMC, the intracellular $\mathrm{Ca}^{2+}$ transients induced by membrane depolarization or vasoactive peptides are sensitive to classic $\mathrm{Ca}^{2+}$ channel blockers (dihydropyridines, benzothiazepines, phenylalkylamines) $(2,4,5)$. The membrane depolarization response to vasoactive peptides is thought to involve activation of $\mathrm{Ca}^{2+}$-dependent $\mathrm{Cl}^{-}$channels and nonselective cation channels in vascular smooth muscle cells (6-8). In renal afferent arteriolar smooth muscle cells, membrane depolarization, elevation in intracellular $\mathrm{Ca}^{2+}$, and contraction in response to the vasoactive peptide endothelin-1 is attenuated by $\mathrm{Cl}^{-}$channel blockers (8). Kurokawa and Okuda (10), Kremer et al. (9), and Palant and Ross (11) present indirect evidence that GMC depolarization after exposure to vasoactive peptides is dependent on a $\mathrm{Ca}^{2+}$-dependent $\mathrm{Cl}^{-}$conductance. However, the mechanism by which vasoactive peptides might depolarize GMC and activate voltage-dependent $\mathrm{Ca}^{2+}$ channels has not been investigated at a single channel level. Using patch clamp methodology, we have identified two $\mathrm{Ca}^{2+}$-dependent ion channels in rat mesangial cell cultures that are capable of membrane depolarization and are activated by the vasoactive peptide, AII, but only in the presence of insulin (Table II).

Low-conductance, $\mathrm{Ca}^{2+}$-activated $\mathrm{Cl}^{-}$channels sensitive to AII. The first is an outwardly rectifying $\mathrm{Cl}^{-}$-selective channel with a unitary conductance of 2-5 pS. With a reversal potential near the resting membrane potential of GMC and a low open probability under baseline conditions $\left(-\mathrm{V}_{\text {pipet }}=0 \mathrm{mV}, 37^{\circ} \mathrm{C}\right.$, physiologic extracellular saline, cell-attached configuration), this low-conductance $\mathrm{Cl}^{-}$channel would generate little $\mathrm{Cl}^{-}$ flux. However, $N P_{\mathrm{o}}$ for this $\mathrm{Cl}^{-}$channel increased $>100 \%$ with exposure to the vasoactive peptide, AII. Stimulation of $\mathrm{Cl}^{-}$ channel activity was seen at 1-, 10-, and 100-nM concentrations of AII. Circulating human plasma AII levels are usually $\leq 50 \mathrm{nM}$ and physiological effects are mimicked by infusion rates that maintain plasma levels in this range (27). 


\begin{tabular}{|c|c|c|c|c|c|}
\hline & $\mathrm{P}_{\mathrm{C}} / \mathrm{P}_{\mathrm{Na}} / \mathrm{P}_{\mathrm{K}}{ }^{*}$ & $\begin{array}{l}\text { Current-voltage } \\
\text { relationship }\end{array}$ & $\begin{array}{l}\text { Direct activation } \\
\text { by acute insulin }\end{array}$ & $\begin{array}{l}\text { Responsive } \\
\text { to } \mathrm{All}^{\ddagger}\end{array}$ & $\begin{array}{l}\text { Open probability at } \\
{\left[\mathrm{Ca}^{2+}\right]_{\mathrm{i}}=10^{-7} \mathrm{M}}\end{array}$ \\
\hline \multicolumn{6}{|l|}{ 4-pS Cl${ }^{-}$channel } \\
\hline Cultures without insulin & & Outwardly rectifying & & No & $0.0002 \pm 0.0008$ \\
\hline Cultures with insulin & $>50: 1: 1$ & Outwardly rectifying & & Yes & $0.05 \pm 0.04$ \\
\hline Acute insulin (low dose) & & Outwardly rectifying & No & Yes & $0.14 \pm 0.04$ \\
\hline Acute insulin (high dose) & & Linear & Yes & Yes & $0.18 \pm 0.10$ \\
\hline \multicolumn{6}{|l|}{$27 \mathrm{pS}$ NSCC } \\
\hline Cultures without insulin & & Linear & & No & $0.0006 \pm 0.0014$ \\
\hline Cultures with insulin & $0.1: 1: 1$ & Linear & & Yes & $0.03 \pm 0.02$ \\
\hline Acute insulin (low dose) & & Linear & No & Yes & $0.09 \pm 0.03$ \\
\hline Acute insulin (high dose) & & Linear & Yes & Yes & $0.12 \pm 0.03$ \\
\hline
\end{tabular}

Cutlures with or without insulin $=$ rat mesangial cell cultures grown with or without insulin $(100 \mathrm{mU} / \mathrm{ml})$. Acute insulin $=$ rat mesangial cell cultures grown without insulin are exposed to insulin for $15 \mathrm{~min}$ before patching. Low dose $=1 \mu \mathrm{U} / \mathrm{ml}$ or $10 \mu \mathrm{U} / \mathrm{ml} \mathrm{insulin;} \mathrm{high} \mathrm{dose}=100$ $\mu \mathrm{U} / \mathrm{ml}$ or $100 \mathrm{mU} / \mathrm{ml}$ insulin. ${ }^{*}$ Excised inside-out patches. ${ }^{\ddagger}$ Cell-attached patches.

In cultured rat GMC, both AII and vasopressin stimulate a macroscopic $\mathrm{Cl}^{-}$permeability associated with the release of intracellular $\mathrm{Ca}^{2+}$ stores (9-11). In response to vasoactive peptides, there is hydrolysis of mesangial cell membrane phospholipids and release of $\mathrm{IP}_{3}$-sensitive intracellular $\mathrm{Ca}^{2+}$ pools $(1$, 24). Thapsigargin is a cell-permeable tumor promotor that rapidly releases $\mathrm{Ca}^{2+}$ from intracellular stores without hydrolysis of inositol polyphosphates in both contractile (vascular smooth muscle, platelets) and noncontractile cells (neuronal, parotid acinar, and cortical collecting tubule) $(16,25,26)$. Supporting the hypothesis that AII activates this 4-pS $\mathrm{Cl}^{-}$ channel by mobilizing intracellular $\mathrm{Ca}^{2+}$, we found that adding thapsigargin caused an $\sim 200 \%$ increase in $\mathrm{NP}_{\mathrm{o}} . \mathrm{Ca}^{2+}$ dependency was confirmed by our observation that directly raising free $\mathrm{Ca}^{2+}$ at the cytoplasmic surface of inside-out patches also increased channel activity.

Palant and associates have described two anion-permeable channels in cultured rat GMC, but with much larger conductances of $48 \mathrm{pS}(28)$ and $62 \mathrm{pS}(29)$. Dependency of these latter two anion channels on intracellular $\mathrm{Ca}^{2+}$ or vasoactive peptides was not reported. Stimulation of low-conductance (2-5 pS) $\mathrm{Cl}^{-}$channels by intracellular $\mathrm{Ca}^{2+}$ has been described in amphibian distal nephron cells $(30,31)$, mouse juxtaglomerular cells (32), rat lacrimal gland cells (33), Xenopus oocytes (34), and porcine intermediate lobe cells (35).

$\mathrm{Ca}^{2+}$-activated nonselective cation channels sensitive to AII. The second channel has a unitary conductance of 25-29 $\mathrm{pS}$, a linear I-V relationship, no voltage dependency, and is nonselective for cations, but relatively impermeable to $\mathrm{Cl}^{-}$. We expect this channel to contribute little to basal ion fluxes since it is quiescent at resting membrane potential and $E_{\mathrm{rev}}$ is near $-V_{\text {pipet }}=0 \mathrm{mV}$. This NSCC was also activated by AII and thapsigargin in cell-attached patches, and cytoplasmic $\mathrm{Ca}^{2+}$ in excised inside-out patches. Stimulation of NSCC channel activity was also observed at physiologic nanomolar concentrations of AII.

Matsunaga et al. (15) recently characterized a $25-\mathrm{pS} \mathrm{Ca}^{2+}$ dependent NSCC that is activated by AII or vasopressin in cultured rat GMC. Palant and associates have also described an osmotically activated NSCC (36) and a 62-pS stretch-activated NSCC (29) in cultured rat GMC. Responses to cytoplasmic $\mathrm{Ca}^{2+}$ and vasoactive peptides were not reported for these latter two NSCC. A family of 20-35-pS NSCC that are activated by intracellular $\mathrm{Ca}^{2+}$ have also been described in nonmesangial cell types, including vestibular dark cells (37), rat insulinoma (38), cardiac ventricular (39), neuroblastoma (40), pancreatic acinar (41), Schwann (42), lacrimal gland (33), thyroid follicular (43), and neutrophils (44).

Modulation of mesangial cell ion channels by exogenous insulin. Studies by Kreisberg (45), and Dunlop and Larkins (12) have demonstrated in cultured rat GMC that the presence of insulin in the growth medium was required for normal intracellular $\mathrm{Ca}^{2+}$ transients and contraction to occur in response to $1 \mathrm{nM}$ to $10 \mu \mathrm{M}$ AII or other vasoconstrictive peptides (e.g., platelet-activating factor, endothelin-1). We found that activation of both the 4-pS Cl${ }^{-}$channel and the 27-pS NSCC by AII or thapsigargin also depended on chronic exposure to $100 \mathrm{mU} /$ $\mathrm{ml}$ insulin. Acute exposure of insulin-deficient GMC cultures to insulin ( $15 \mathrm{~min}$ ) directly increased the activity of both channels at dosages $\geq 100 \mu \mathrm{U} / \mathrm{ml}$ and restored channel responsiveness to AII at dosages $\geq 1 \mu \mathrm{U} / \mathrm{ml}$. Excised patch experiments revealed that insulin deficiency decreased the sensitivity of the $\mathrm{Cl}^{-}$channel and NSCC to activation by cytoplasmic $\mathrm{Ca}^{2+}$. Comparing cultured rat GMC grown with and without insulin, open probability for both the $\mathrm{Cl}^{-}$channel and NSCC increased 100-fold for excised patches exposed to $10^{-7} \mathrm{M} \mathrm{Ca}^{2+}$ in the cytoplasmic bath (Table II). Mesangial cell intracellular $\mathrm{Ca}^{2+}$ concentrations range from $10^{-7}$ to $10^{-6} \mathrm{M}$ under baseline or vasoactive peptide-stimulated conditions $(9,24)$. Using fura2-loaded rat GMC, Dunlop and Larkins (12) have shown that $\mathrm{IP}_{3}$-sensitive $\mathrm{Ca}^{2+}$ release itself is also attenuated in insulin-deficient GMC cultures.

Variable GMC responsiveness to AII under our different insulin exposure conditions could be mediated by alterations in AII ligand-receptor binding. Our results show that ${ }^{125}$ I AII binds to rat GMC cultures in a saturable manner. AII binding decreased by $86 \%$ when $100 \mathrm{mU} / \mathrm{ml}$ insulin was removed from our standard growth medium. This decreased binding in the absence of chronic insulin exposure was due to a marked reduction in the number of AII receptor binding sites, rather than a change in receptor binding affinity. In contrast, acute exposure of insulin-deficient GMC to either low- $(10 \mu \mathrm{M} / \mathrm{ml})$ or high-dose $(100 \mathrm{mU} / \mathrm{ml})$ insulin for $15 \mathrm{~min}$ did not signifcantly change the number of binding sites, or the binding affin- 
ity. In GMC cultured without supplemental insulin, other investigators have shown that AII binds only to a single class of AII receptor subtype $1\left(\mathrm{AT}_{1}\right)$ receptors with $K_{\mathrm{d}}$ 's ranging from 0.37 to $2.8 \mathrm{nM}$, and $B_{\max }$ 's ranging from 6.93 to $43.5 \mathrm{fmol} / \mathrm{mg}$ protein in rat (passage unknown) (22), murine (continuous cell line) (20), and human (passages 3-6) (21) GMC. Binding studies for human fetal and adult GMC (passages 4-11) grown with $8 \mu \mathrm{M}(1 \mathrm{U} / \mathrm{ml})$ insulin show a $K_{\mathrm{d}}$ of $1.25-1.6 \mathrm{nM}$ and $B_{\max }$ of $65-70 \mathrm{fmol} / 10^{5}$ cells (23) (insulin concentration conversions: $7.175 \mu \mathrm{M}=1 \mathrm{U} / \mathrm{ml}[46]$ and $1 \mu \mathrm{g} / \mathrm{ml}=24 \mathrm{mU} / \mathrm{ml}$ [Sigma Chemical Co.]). Using rat GMC passages 5-7, our $K_{d}$ and $B_{\max }$ values are consistent with these previous studies. Our results indicate that the insulin-dependent responsiveness of $\mathrm{Cl}^{-}$and NSCC to activation by AII and intracellular $\mathrm{Ca}^{2+}$ is time dependent. Acute exposure ( $\mathrm{min}$ ) of GMC to exogenous insulin has no affect on AII receptor binding affinity or receptor density. However, chronic exposure (d) to insulin results in an increase in AII receptor density.

Both acute and chronic insulin exposure shifts the $\mathrm{Ca}^{2+}$ activation curves for the $\mathrm{Cl}^{-}$and NSCC, making them more sensitive to intracellular $\mathrm{Ca}^{2+}$. This effect was observed in patches excised from GMC and independent of AII receptor interactions. Therefore, channel activation and restoration of AII responsiveness after acute or chronic insulin exposure must also be mediated by another signaling mechanism, independent of insulin's affects on AII ligand-receptor binding.

What insulin-mediated signaling mechanisms might affect the $\mathrm{Ca}^{2+}$-dependent, 4-pS $\mathrm{Cl}^{-}$channel and 27-pS NSCC in glomerular mesangial cells? Insulin regulates membrane phospholipid metabolism: hydrolysis of phosphatidylinositol-glycan, stimulation of phosphatidic acid synthesis, and hydrolysis of phosphatidylcholine by phospholipases $C$ and $D(47)$. All of these phospholipid effects generate diacylglycerol and $\mathrm{IP}_{3}$, the latter stimulating the release of intracellular $\mathrm{Ca}^{2+}$ stores and potentiating the activation of these $\mathrm{Ca}^{2+}$-activated channels.

Generation of diacyglycerol by insulin also activates $\mathrm{Ca}^{2+}$. and phospholipid-dependent protein kinase $C$ (47), which inhibits atrial natriuretic peptide (ANP)-induced stimulation of particulate guanylyl cyclase in GMC (48). AII-induced GMC contractions and elevations in intracellular $\mathrm{Ca}^{2+}$ are inhibited by guanylyl cyclase stimulation and elevated intracellular cGMP levels $(48,49)$. If cGMP levels were elevated in GMC grown without insulin, it could explain the observed insensitivity of 4-pS Cl${ }^{-}$channels and 27-pS NSCCs to AII under insulin-deficient growth conditions. However, in the presence of AII, basal cGMP levels are reduced, not elevated, in rat GMC and murine mesangial cell cultures grown without supplemental insulin $(20,48)$. ANP is the only receptor-mediated agonist of guanylyl cyclase that has been identified in GMC (1). But, even after exposure to both ANP and AII, cGMP levels in GMC are similar to unstimulated basal values (20). GMC also contain a soluble form of guanylyl cyclase that is activated by endothelial cell-derived nitric oxide (49). While nitrates also appear to affect intracellular $\mathrm{Ca}^{2+}$, GMC were not cocultured with endothelial cells in the present study. Therefore, changes in intracellular cGMP probably do not explain the difference in AII responsiveness between insulin-treated and insulin-deficient GMC.

Marunaka and Eaton $(30,31)$ have characterized a 3-pS $\mathrm{Ca}^{2+}$-dependent $\mathrm{Cl}^{-}$channel in an amphibian distal nephron cell line (A6) that was stimulated by insulin. Insulin increased $P_{\text {o }}$, linearlized the outwardly rectifying $\mathrm{I}-\mathrm{V}$ curve, and caused a 100-fold decrease in the threshold cytoplasmic $\mathrm{Ca}^{2+}$ concentration required for channel activation. They found that alkaline phosphatase mimicked the effects of insulin and hypothesized that dephosphorylation was responsible for the observed channel activation. We noted that insulin promotes the hydrolysis of phosphatidylinositol-glycan, which in turn generates products that activate intracellular phosphatases (47). Modulation of intracellular $\mathrm{Ca}^{2+}$ sensitivity for $\mathrm{Ca}^{2+}$-dependent ion channels by dephosphorylation/phosphorylation reactions has been proposed by others $(9,30,31,38,50,51)$.

Role for mesangial cell ion channels in the pathogenesis of diabetic glomerular hyperfiltration. Our findings suggest that impaired activation of the mesangial cell ion channels described in this study would be expected in patients with insulinopenic and, perhaps, insulin-resistent diabetes mellitus. This would result in impaired depolarization in response to vasoactive peptides, decreased $\mathrm{Ca}^{2+}$ influx through voltage-activated $\mathrm{Ca}^{2+}$ channels, decreased GMC contractility, increased glomerular capillary ultrafiltration coefficient $\left(K_{\mathrm{f}}\right)$, and an increase in glomerular filtration (Fig. 15). Impaired contraction of vascular smooth muscle cells is also seen in the afferent arterioles of streptozotocin-treated diabetic rats and is improved by insulin therapy (52). Renal micropuncture and clearance studies have shown that the elevated glomerular filtration rate, single nephron filtration rate, glomerular hydraulic pressure, and renal plasma flow observed in streptozotocintreated diabetic rats is reduced by intrarenal infusion of insulin and calcium (13). Diabetic glomerular hyperfiltration was restored if the $\mathrm{Ca}^{2+}$ channel blocker, verapamil, was infused after insulin and calcium.

Previous work on cultured rat GMC studied the effects of relatively high insulin concentrations (insulin concentration conversions: $7.175 \mu \mathrm{M}=1 \mathrm{U} / \mathrm{ml}$ [46] and $1 \mu \mathrm{g} / \mathrm{ml}=24$

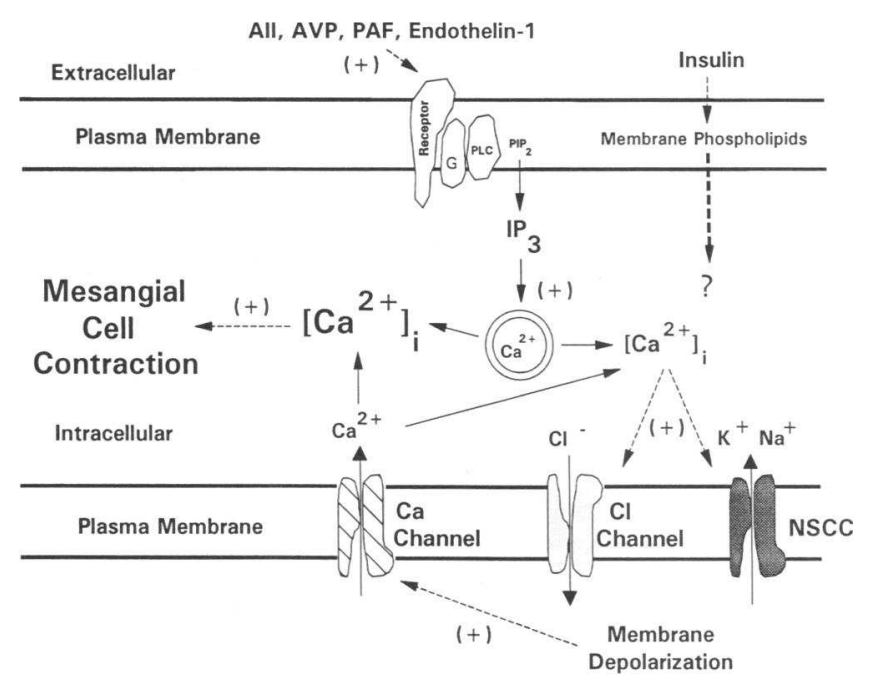

Figure 15. Model for regulation of glomerular mesangial cell ion channels. (Top) Vasoactive peptides stimulate receptor-mediated phospholipid hydrolysis generating $\mathrm{IP}_{3}$. (Bottom right) Intracellular $\mathrm{Ca}^{2+}$ release stimulates $\mathrm{Ca}^{2+}$-dependent, $\mathrm{Cl}^{-}$channels and NSCCs. (Bottom) $\mathrm{Cl}^{-}$efflux and cation influx, respectively, cause membrane depolarization and activation of voltage-dependent $\mathrm{Ca}^{2+}$ channels. (Middle) $\mathrm{Ca}^{2+}$ influx results in mesangial cell contraction and decreased glomerular capillary ultrafiltration coefficient $\left(K_{\mathrm{f}}\right)$. (Top) Exogenous insulin modulates $\mathrm{Cl}^{-}$channel and NSCC activity, likely through affects on mesangial cell membrane phospholipid metabolism (see Discussion). 
$\mathrm{mU} / \mathrm{ml}$ [Sigma Chemical Co.]): $0.7 \mathrm{nM}(98 \mu \mathrm{U} / \mathrm{ml}), 4 \mu \mathrm{g} / \mathrm{ml}$ $(96 \mathrm{mU} / \mathrm{ml})$, and $7 \mu \mathrm{M}(976 \mathrm{mU} / \mathrm{ml})(12,45)$. However, the glomerular hyperfiltration observed in streptozotocin-treated diabetic rats is acutely decreased with intrarenal infusion of much lower doses of insulin $(0.5 \mu \mathrm{U} / \mathrm{ml})(13,53)$. Therefore, we evaluated the responses of insulin-deficient rat GMC cultures acutely exposed to more physiologic insulin concentrations. $\mathrm{Cl}^{-}$and NSCC were not directly stimulated, but responsiveness to AII and cytoplasmic $\mathrm{Ca}^{2+}$ was restored with insulin concentrations of 1 and $10 \mu \mathrm{U} / \mathrm{ml}$. Higher insulin dosages $(100 \mu \mathrm{U} / \mathrm{ml}$ and $100 \mathrm{mU} / \mathrm{ml})$ also restored channel responsiveness to vasoactive peptide and $\mathrm{Ca}^{2+}$, in addition to directly stimulating $\mathrm{Cl}^{-}$and NSCC activity.

Normal fasting plasma insulin levels in humans are 5-20 $\mu \mathrm{U} / \mathrm{ml}$, and in response to a high carbohydrate meal, levels increase to $\sim 70 \mu \mathrm{U} / \mathrm{ml}$ in normal, $175 \mu \mathrm{U} / \mathrm{ml}$ in hypertensive, and $250 \mu \mathrm{U} / \mathrm{ml}$ in obese individuals $(46,54)$. In normal subjects receiving a constant insulin infusion $(0.05 \mathrm{U} / \mathrm{kg}$ per h), steady-state plasma insulin levels are $134 \mu \mathrm{U} / \mathrm{ml}$, with even higher peak levels expected with intermittent injections (55). These data indicate that physiologic concentrations of insulin restore or mediate the response of glomerular mesangial cells to vasoactive peptides and cytoplasmic $\mathrm{Ca}^{2+}$.

Conclusions. We present single channel data showing two ion channels capable of depolarizing glomerular mesangial cells in response to the vasoactive peptide, AII: $\mathrm{Ca}^{2+}$-dependent, 4-pS $\mathrm{Cl}^{-}$channels promoting $\mathrm{Cl}^{-}$efflux; and $\mathrm{Ca}^{2+}$-dependent, 27-pS nonselective cation channels promoting cation influx.

The activity of both channels and their responsiveness to AII and intracellular $\mathrm{Ca}^{2+}$ are dependent on the presence of exogenous insulin. Both acute and chronic insulin exposures raise the sensitivity of both channels to intracellular $\mathrm{Ca}^{2+}$ through a non-AII receptor-mediated mechanism. Chronic, but not acute, insulin exposure also increases AII receptor density by $>85 \%$, while $K_{d}$ is unaffected. Regulation of the 4-pS $\mathrm{Cl}^{-}$channel and the 27-pS NSCC by insulin provides a mechanism for the impaired $\mathrm{Ca}^{2+}$ uptake by glomerular mesangial cells observed in association with insulin deficiency. Thus, insulinopenia or insulin resistance could play an essential role in the early glomerular hyperfiltration that is observed in diabetes mellitus and that correlates with the development of proteinuria and diabetic nephropathy (13).

\section{Acknowledgments}

We are indebted to Christine L. Webster for her skillful technical assistance in the preparation and maintenance of the mesangial cell cultures.

B.N.Ling is supported by National Institutes of Health (NIH) grant K08 DK-02111 and a Veterans Administration Merit Review Award, and D.C.E. is supported by NIH grant R01 DK-37963.

\section{References}

1. Mene, P., M. S. Simonson, and M. J. Dunn. 1989. Physiology of mesangial cell. Physiol. Rev. 69:1347-1424.

2. lijima, K., and M. S. Goligorsky. 1990. Characterization of voltage-sensitive $\mathrm{Ca}^{2+}$ channels (VSCC) in mesangial (MC) and vascular smooth muscle cells (VSMC) of Dahl prehypertensive rats. Kidney Int. 37:387.(Abstr.)

3. Matsunaga, H., H. Chang, T. Okuda, S. Uchida, and K. Kurokawa. 1989. Evidence for voltage-gated calcium channel current in rat mesangial cells in culture. Kidney Int. 35:177.(Abstr.)

4. Yu, Y-M., F. Lermioglu, and A. Hassid. 1989. Modulation of Ca by agents affecting voltage-sensitive Ca channels in mesangial cells. Am. J. Physiol. 257:F1094-F1099.

5. Nishio, M., H. Tsukahara, M. Hiraoka, M. Sudo, S. Kigoshi, and I. Muramatsu. 1993. Calcium channel current in cultured rat mesangial cells. Mol. Pharmacol. 43:96-99.

6. Nelson, M. T., J. B. Patlak, J. F. Worley, and N. B. Standen. 1990. Calcium channels, potassium channels, and voltage dependence of arterial smooth muscle tone. Am. J. Physiol. 259:C3-C18.

7. Marsden, P. A., and B. M. Brenner. 1991. Nitric oxide and endothelins: novel autocrine/paracrine regulators of the circulation. Semin. Nephrology. 11:169-185.

8. Takenaka, T., M. Epstein, H. Forster, D. W. Landry, K. lijima, and M. S. Goligorsky. 1992. Attenuation of endothelin effects by a chloride channel inhibitor, indanyloxyacetic acid. Am. J. Physiol. 262:F799-F806.

9. Kremer, S. G., W. Zeng, S. Sridhara, and K. L. Skorecki. 1992. Multiple signaling pathways for $\mathrm{Cl}^{-}$-dependent depolarization of mesangial cells: role of $\mathrm{Ca}^{2+}$, PKC, and G proteins. Am. J. Physiol. 262:F668-F678.

10. Kurokawa, K., and T. Okuda. 1990. Calcium-activated chloride conductance of mesangial cells. Kidney Int. 38:S48-S50.

11. Palant, C. E., and M. J. Ross. 1991. Role of ionic currents in the physiological response to angiotensin II. Renal Physiol. Biochem. 14:186-198.

12. Dunlop, M. E., and R. G. Larkins. 1990. Insulin-dependent contractility of glomerular mesangial cells in response to angiotensin II, platelet-activating factor and endothelin is attenuated by prostaglandin $E_{2}$. Biochem. J. 272:561568 .

13. Bank, N. 1991. Mechanisms of diabetic hyperfiltration. Kidney Int. 40:792-807.

14. Hassid, A., N. Pidikiti, and D. Gamero. 1986. Effects of vasoactive peptides on cytosolic calcium in cultured mesangial cells. Am. J. Physiol. 251:F1018F1028.

15. Matsunaga, H., N. Yamashita, Y. Miyajima, T. Okuda, H. Chang, E. Ogata, and K. Kurokawa. 1991. Ion channel activities of cultured rat mesangial cells. Am. J. Physiol. 261:F808-F814.

16. Ling, B. N., K. E. Kokko, and D. C. Eaton. 1992. Inhibition of apical $\mathrm{Na}^{+}$ channels in rabbit cortical collecting tubules by basolateral prostaglandin $E_{2}$ is modulated by protein kinase C. J. Clin. Invest. 90:1328-1334.

17. Fabiato, A. 1988. Computer programs for calculating total from specified free or free from specified total ionic concentrations in aqueous solutions containing multiple metals and ligands. Methods Enzymol. 157:378-417.

18. Marunaka, Y., and D. C. Eaton. 1991. Effects of vasopressin and cAMP on single amiloride-blockable Na channels. Am. J. Physiol. 260:C1071-C1084.

19. Freund, J. E., and R. E. Walpole. 1987. Sampling distributions. In Mathematical Statistics. Prentice Hall, Englewood Cliffs, NJ. 271-305.

'20. Wolf, G., F. Thaiss, W. Schoeppe, and R. A. K. Stahl. 1992. Angiotensin II-induced proliferation of cultured murine mesangial cells: inhibitory role of atrial natriuretic peptide. J. Am. Soc. Nephrol. 3:1270-1278.

21. Chansel, D., S. Czekalski, P. Pham, and R. Ardaillou. 1992. Characterization of angiotensin II receptor subtypes in human glomeruli and mesangial cells. Am. J. Physiol. 262:F432-F441.

22. Foidart, J., J. Sraer, F. Dularue, P. Mahieu, and R. Ardaillou. 1980. Evidence for mesangial glomerular receptors for angiotensin II linked to mesangial cell contractility. FEBS (Fed. Eur. Biochem. Soc.) Lett. 121:333-339.

23. Ray, P. E., G. Aguilera, J. B. Kopp, S. Horikoshi, and P. E. Klotman. 1991. Angiotensin II receptor-mediated proliferation of cultured human fetal mesangial cells. Kidney Int. 40:764-771.

24. Mene, P., M. S. Simonson, and M. J. Dunn. 1989. Phospholipids in signal transduction of mesangial cells. Am. J. Physiol. 256:F375-F386.

25. Xuan, Y-T., O-L. Wang, and R. Whorton. 1992. Thapsigargin stimulates $\mathrm{Ca}^{2+}$ entry in vascular smooth muscle cells: nicardipine-sensitive and -insensitive pathways. Am. J. Physiol. 262:C1258-C1265.

26. Baro, I., and D. A. Eisner. 1992. The effects of thapsigargin on $\left[\mathrm{Ca}^{2+}\right]_{i}$ in isolated rat mesenteric artery vascular smooth muscle cells. Pflugers Arch. Eur. $J$. Physiol. 420:115-117.

27. Hall, J. E., and M. W. Brands. 1992. The renin-angiotensin-aldosterone systems: renal mechanisms and circulatory homeostasis. In The Kidney: Physiology and Pathophysiology. D. W. Seldin and G. Giebisch, editors. Raven Press, Ltd., New York. 1455-1504.

28. Palant, C. E., M. J. Ross, D. Harris, G. Berlyne, and W. Craelius. 1990. A voltage-activated anion channel in rat mesangial cells (RMC's). J. Am. Soc. Nephrol. 1:727.(Abstr.)

29. Craelius, W., N. El-Sherif, and C. E. Palant. 1989. Stretch-activated ion channels in cultured mesangial cells. Biochem. Biophys. Res. Commun. 159:516521 .

30. Marunaka, Y., and D. A. Eaton. 1990. Chloride channels in the apical membrane of a distal nephron 6 cell line. Am. J. Physiol. 258:C352-C368.

31. Marunaka, Y., and D. C. Eaton. 1990. Effects of insulin and phosphatase on a $\mathrm{Ca}^{2+}$-dependent $\mathrm{Cl}^{-}$channel in a distal nephron cell line (A6). J. Gen Physiol. 95:773-789.

32. Kurtz, A. 1990. Do calcium-activated chloride channels control renin secretion. News Physiol. Sci. 5:43-46. 
33. Marty, A., Y. P. Tan, and A. Trautman. 1984. Three types of calcium-dependent channels in rat lacrimal glands. J. Physiol. 357:293-325.

34. Takahashi, T., E. Neher, and B. Sakmann. 1987. Rat brain serotonin receptors in Xenopus oocytes are coupled by intracellular calcium to endogenous channels. Proc. Natl. Acad. Sci. USA. 84:5063-5067.

35. Taleb, O., P. Feltz, J. -L. Bossu, and A. Feltz. 1988. Small-conductance chloride channels activated by calcium on cultured endocrine cells from mammalian pars intermedia. Pflugers Arch. Eur. J. Physiol. 412:641-646.

36. Craelius, W., D. R. Harris, and C. E. Palant. 1991. Ionic basis of osmoregulation by rat mesangial cells (RMCs). J. Am. Soc. Nephrol. 2:734.(Abstr.)

37. Marcus, D. C., S. Takeuchi, and P. Wangemann. 1992. $\mathrm{Ca}^{2+}$-activated nonselective cation channel in apical membrane of vestibular dark cells. $\mathrm{Am}$. J. Physiol. 262:C1423-C1429.

38. Sturgess, N. C., C. N. Hales, and M. L. J. Ashford. 1987. Calcium and ATP regulate the activity of a non-selective cation channel in a rat insulinoma cell line. Pflugers Arch. Eur. J. Physiol. 409:607-615.

39. Neher, E., D. Colquhoun, H. Reuter, and C. F. Stevens. 1981. Inward current channels activated by intracellular $\mathrm{Ca}$ in cultured cardiac cells. Nature (Lond.). 294:752-754.

40. Yellen, G. 1982. Single $\mathrm{Ca}^{2+}$-activated nonselective cation channels in neuroblastoma. Nature 296:357-359.

41. Maruyama, Y., and O. H. Petersen. 1982. Single-channel currents in isolated patches of plasma membrane from basal surface of pancreatic acini. Nature (Lond.). 299:159-161.

42. Bevan, S., P. T. A. Gray, and J. M. Ritchie. 1984. A calcium-activated cation-selective channel in rat cultured Schwann cells. Proc. R. Soc. Lond. B. Biol. Sci. 222:349-355.

43. Maruyama, Y., D. Moore, and O. H. Petersen. 1985. Calcium-activated cation channel in rat thyroid follicular cells. Biochim. Biophys. Acta. 821:229232.

44. von Tscharner, V., B. Prodhom, M. Baggiolini, and H. Reuter. 1986. Ion channels in human neutrophils activated by a rise in free cytosolic calcium concentration. Nature (Lond.). 324:369-372.
45. Kreisberg, J. I. 1982. Insulin requirement for contraction of cultured rat glomerular mesangial cells in response to angiotensin II: Possible role for insulin in modulating glomerular hemodynamics. Proc. Natl. Acad. Sci. USA. 79:41904192.

46. Reaven, G. M. 1991. Insulin resistance, hyperinsulinemia, and hypertriglyceridemia in the etiology and clinical course of hypertension. Am. J. Med. 90:2A7S-2A12S.

47. Farese, R. V. 1988. Phospholipid signaling systems in insulin action. Am. J. Med. 85(Suppl. 5A):36-43.

48. Haneda, M., R. Kikkawa, S. Maeda, M. Togawa, D. Koya, N. Horide, N. Kajiwara, and Y. Shigeta. 1991. Dual mechanism of angiotensin II inhibits ANPinduced mesangial cGMP accumulation. Kidney Int. 40:188-194.

49. Mene, P., G. A. Cinotti, and F. Pugliese. 1992. Signal transduction in mesangial cells. J. Am. Soc. Nephrol. 2:S100-S106.

50. Levitan, I. B. 1985. Phosphorylation of ion channels. J. Membr. Biol. 87:177-190.

51. Eaton, D. C., Y. Marunaka, and B. N. Ling. 1992. Ion channels in epithelial tissue: single-channel properties. In Membrane Transport in Biology. J. A. Schafer, H. H. Ussing, P. Kristensen, and G. H. Giebisch, editors. Springer-Verlag, Berlin. 73-165.

52. Hayashi, K., M. Epstein, R. Loutzenhiser, and H. Forster. 1992. Impaired myogenic responsiveness of the afferent arteriole in streptozotocin-induced diabetic rats: role of eicosanoid derangements. J. Am. Soc. Nephrol. 2:1578-1586.

53. Bank, N., M. A. Lahora, and H. S. Aynedjian. 1987. Acute effect of calcium and insulin on hyperfiltration of early diabetes. Am. J. Physiol. 252:E13E20.

54. Bagdade, J. D., E. L. Bierman, and D. Porte, Jr. 1967. The significance of basal insulin levels in the evaluation of the insulin response to glucose in diabetic and nondiabetic subjects. J. Clin. Invest. 46:1549-1557.

55. Nelson, R. L., J. A. Galloway, S. M. Wentworth, and J. A. Caras. 1976. The bioavailability, pharmacokinetics, and time action of regular and modified insulins in normal subjects. Diabetes. 25:325. (Abstr.) 